Florida International University

FIU Digital Commons

3-27-2019

\title{
Illustrating Jain Ethics in Medieval Didactic Literature: Virtue, Karma and Female Agency in the Lilavatisara
}

Carol Rodriguez

Florida International University, crodr364@fiu.edu

Follow this and additional works at: https://digitalcommons.fiu.edu/etd

Part of the Ethics in Religion Commons, and the Translation Studies Commons

\section{Recommended Citation}

Rodriguez, Carol, "Illustrating Jain Ethics in Medieval Didactic Literature: Virtue, Karma and Female Agency in the Lilavatisara" (2019). FIU Electronic Theses and Dissertations. 4028.

https://digitalcommons.fiu.edu/etd/4028

This work is brought to you for free and open access by the University Graduate School at FIU Digital Commons. It has been accepted for inclusion in FIU Electronic Theses and Dissertations by an authorized administrator of FIU Digital Commons. For more information, please contact dcc@fiu.edu. 


\title{
FLORIDA INTERNATIONAL UNIVERSITY
}

\author{
Miami, Florida
}

\section{ILLUSTRATING JAIN ETHICS IN MEDIEVAL DIDACTIC LITERATURE: VIRTURE, KARMA AND FEMALE AGENCY IN THE LILAVATISARA}

\author{
A thesis submitted in partial fulfillment of the \\ requirements for the degree of \\ MASTER OF ARTS \\ in \\ RELIGIOUS STUDIES
}

by

Carol Rodriguez

2019 
To: Dean John F. Stack

Steven J. Green School of International and Public Affairs

This thesis, written by Carol Rodriguez, and entitled Illustrating Jain Ethics in Medieval Didactic Literature: Virtue, Karma and Female Agency in The Līlāvatīsāra, having been approved in respect to style and intellectual content, is referred to you for judgment.

We have read this thesis and recommend that it be approved.

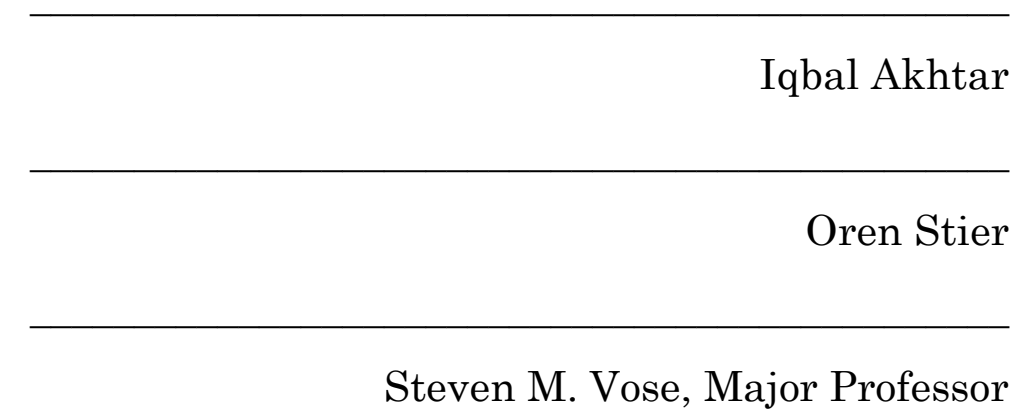

Date of Defense: March 27, 2019

This thesis of Carol Rodriguez is approved.

Dean John F. Stack Steven J. Green School of International and Public Affairs

Andrés G. Gil Vice President for Research and Economic Development and Dean of the University Graduate School

Florida International University, 2019 
(C) Copyright 2019 by Carol Rodriguez

All rights reserved. 


\section{DEDICATION}

To my wonderful family,

who has loved and supported me in all my academic adventures. 


\section{ACKNOWLEDGMENTS}

I want to acknowledge the immense group of people who guided me and enhanced both my research project and my overall academic experience.

I would like to express my sincere gratitude to my thesis advisor and mentor Dr. Steven Vose. His patience, guidance and overwhelming enthusiasm catalyzed the awakening of my ever-growing academic curiosity. His valuable insight and supervision, as well as his ability to improve my critical thinking skills truly helped me bring this project to completion. Lastly, I want to thank him for supporting my decision to pursue an academic career and for believing in my ability to achieve that.

I want to extend my gratitude towards Dr. Oren Stier and Dr. Iqbal Akhtar who have patiently and kindly supported my project as it grew and evolved: Dr. Stier has greatly influenced my academic approach and provided me with guidance and support as I decided to pursue this degree. His enthusiasm and validation were tremendous motivators during my academic transition. Dr. Akhtar provided me with knowledge and inspiration as an undergraduate and his feedback on my graduate project has helped me look beyond my own boundaries.

I want to also extend my acknowledgments to the Jain Community of South Florida and to Latika and Rajiv Jain whose fellowship not only allowed me to complete my project but to share it at multiple conferences and events. 
Lastly, I want to thank my family, my mother Liliana and father Emilio for their unconditional love and support. My uncle Albert, auntie Maidole and my cousins for encouraging me and giving me hope during my hardest days. I want to thank my grandfather and grandmother who have both supported my decisions and loved me every step of the way. I could have not done this without them. 


\section{ABSTRACT OF THE THESIS}

\section{ILLUSTRATING JAIN ETHICS IN MEDIEVAL DIDACTIC LITERATURE: VIRTURE, KARMA AND FEMALE AGENCY IN THE LILAVATISARA}

by

Carol Rodríguez

Florida International University, 2019

Miami, Florida

\section{Professor Steven M. Vose, Major Professor}

This thesis presents an analysis of virtue as it is illustrated in Jinaratna-Suri's Lìlāvatīsāra (Epitome of Queen Līlāvatì). By the deliberate use of simple yet remarkably clear and straightforward language, this text is able to depict the methods necessary for acting virtuously while solidifying spiritual archetypes that operate in a social context.

In this project, I argue that Virtue and the Western definition of goodness, work as parallel yet independent ideas. Behavior becomes a sign of (the level of one's) spiritual advancement, which takes on different natures depending on the underlying motivations of the characters. Thus, as far as it is represented in this text, virtuousness is intrinsically linked with the operative aspect of karma, or karmic fruition, which works in the world with fate and human agency. 
My research also argues that the combination of these prior phenomena, effectively illustrated through allegory, leaves very little opportunity for female agency to operate. Women's virtuousness becomes one that portrays female characters as "the other" and marginalizes the roles they play accordingly. The text groups these characters into archetypes of a rather negative nature, which hampers the development of their literary personas. Because of the repetition of such characterizations, these female characters become representatives of their whole group, solidifying their own spiritual boundaries in the process. 


\section{TABLE OF CONTENTS}

CHAPTER

PAGE

INTRODUCTION 1

CHAPTER I: The Līlāvatīsāra and its Translations.......................................10

I.I Didactic Tales and Their Significance.............................................10

I.II The Stories of the Līlāvatīsāra.........................................................12

(i) The King and his Obstinate Queen.................................................. 12

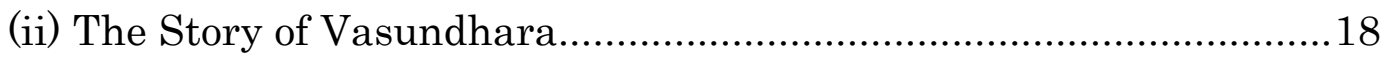

(iii) Buddhisagara and the Astrologer's Prediction..............................24

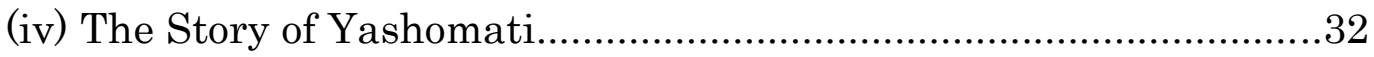

(v) The Story of Princess Durlabhika.....................................................42

CHAPTER II: Virtue in Didactive Narrative: Re-Defining Good and ReAssessing Human Worth................................................................................46

II.I The Differences Between Virtue and Goodness as Rendered in Jain Medieval Literature...................................................................46

II.II Perpetuating Virtue.......................................................52

II.III Virtue Prescribed for the Virtuous: The Abstract Value of

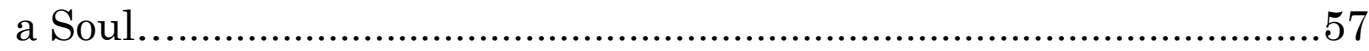

II.IV Narrating Virtue: The Righteous

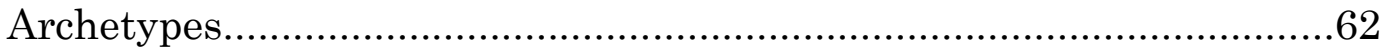

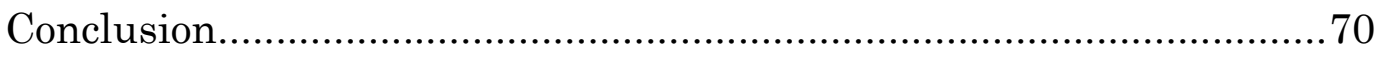

CHAPTER III: Sources of Virtue in Narrative: Karma, Destiny

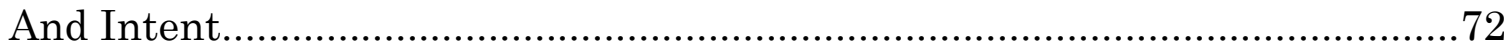

III.I Virtue and its Catalyzers: Understanding Goodness as Attributed to Karma and Fate. 
III.II Karma and Fate: An Ambiguous Correspondence.........................79

III.III Accepting Fate, Karma and Inevitability as Independent, Interconnected Phenomena.................................................................... 91

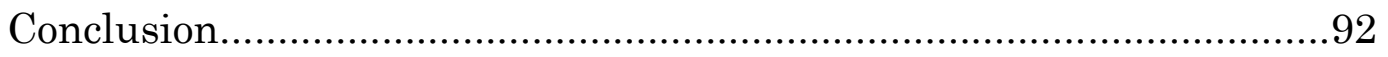

CHAPTER IV: Women in Narrative: The Limitations of Female Agency and the Place of Women as the "Other" in the Līlāvatīsāra.............................94

IV.I The Absence of Queen Lìlāvatīi: The Role of Indian Women in

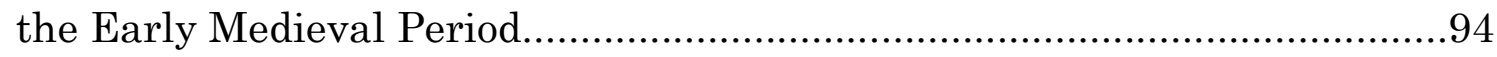

IV.II Rethinking the Archetypes: The Temptress, the Obstinate

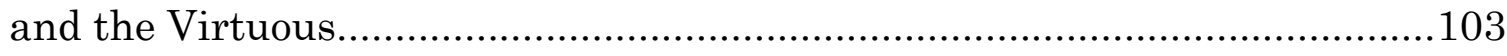

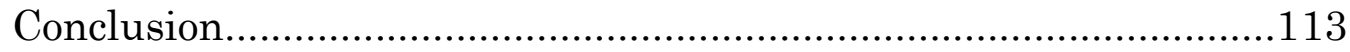

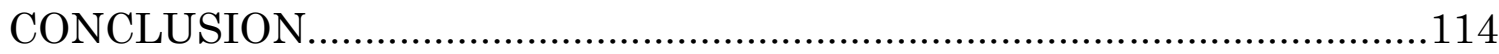

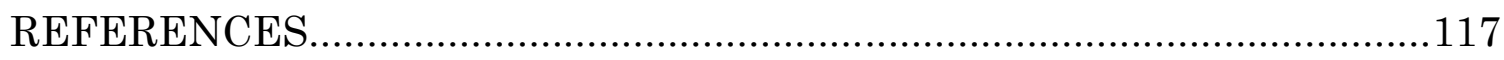




\section{INTRODUCTION}

The analysis of virtue in Jainism cannot be accomplished by addressing canonical and ecclesiastic work alone. Because this topic is often explored through popular literature, both representations need to be acknowledged and understood. Piety and good behavior within didactive works are represented in quite a particular way, especially when both scholars and practitioners take karma, human agency and gender roles into account. Understanding good behavior and the motivations that drive it are crucial to the ultimate goal of every Jain, which is to achieve spiritual maturity and with that, eternal relief from the cycle of rebirths (moksha). However, because of the underlaying layer of anthropocentrism that is embedded in the Jain spiritual hierarchy, delving into the narrative illustration of these qualities becomes a challenge to both, the academic and lay audience (Appleton 2015, 155). As it is prescribed in the Tattvartha Sutra (Sukhlalji 2000), ${ }^{1}$ the most critical requisite for attaining liberation in the Jain community is the need to follow the Three Jewels (ratnatraya): right faith, right knowledge and right conduct. These prescribe the correct way to live. In order to abide by these principles effectively, every practitioner must conduct his/herself according to the "five great vows" or

\footnotetext{
${ }^{1}$ Please refer to Pt. Sukhlalji's commentary on Tattvārtha sūtra of Vācaka Umāsvāti, translated by K.K. Dixit.
} 
mahavratas. $^{2}$ Expressions of virtue as representative of these vows in Jain medieval narrative are dependent not only on the individual's stage in life (whether they are a lay practitioner or part of the monastic order) but seems to also be affected by such individual's gender. The influence of karma, fate and human agency as they are rendered through allegorical stories can either support or challenge the model of virtuousness that effectually reflects and perpetuates masculinity as the normative representation of spiritual growth. Through India's history, and through the thousands of stories that augment its many religions, there is an interesting and dynamic relationship between the concept of morals and good behavior as they apply to men and women in a rather different way. Because Jains were no strangers to this phenomenon, and yet, were also able to beautifully reflect their ontological particularities through narrative, their work will serve as our model.

The purpose of this research then is to explore the particularities of virtue $^{3}$ as it is rendered in Jain didactic literature, focusing specifically on the Lìlāvatīsāra (Epitome of Queen Lìlāvatì). By analyzing the representation of good behavior in this text and framing the use of allegory, carefully designed archetypes and the expression of layered lessons written under a deliberate

\footnotetext{
2 Ahimsa (non-violence), Satya (truthfulness), Asteya (not stealing), Aparigraha (nonacquisition), Brahmacarya (chaste living).

${ }^{3}$ Virtue as a moral state (shila).
} 
textual simplicity, I argue that, this text shows how Jains reflect on the complications and/or difficulties that living presents to the acceptance (and enactment) of challenges illustrated by doctrinal texts as the path to selfrealization or liberation. This text highlights and examines the complications that occur in the every-day setting and proposes the most virtuous solutions to such. The piece is embedded with layers of socio-cultural lessons and serves to solidify normative ideas of virtuousness and good behavior.

Further, although this literary piece does not actively declare that the spiritual level of women is lesser compared to that of men, it does however frame female characters in a light of inferiority much more often than it does their masculine counterparts. This is accomplished by grouping and illustrating both women and animal characters into common archetypes that limit their significance in the stories. In many instances, women's virtue is used as a patriarchal tool, framing the role of virtuous woman as a representation of an anomaly, an exception to the rule, instead of a justification of spiritual equality.

The Lìlāvatīsāra ${ }^{4}$ was written by the Svetambara Kharatara Gaccha monk Jinaratnasuri around the year $1285 \mathrm{CE}$. This monk was but one of the many Kharatara Gaccha authors of his time. His work was just a small part of

\footnotetext{
${ }^{4}$ Referred to as LVS from this point on.
} 
the vast amount of literature produced by his monastic lineage in the thirteenth century. Different from other texts of its period however, this abridgment of Jineshvarasuri's Nirvānalīlāvaīkahā ( or the final liberation of Līlāvatī) was preserved in only one manuscript, kept in the Kharatara Gaccha Bhandar ${ }^{5}$ collection in Jaisalmer. Although this text had not garnered a large response from the community, it is still an interesting and rather singular representation of the narratives of the time. It mainly focuses on the process of finding liberation through virtuous acts and by avoiding immoral decision making. It highlights the impact of karma as having both individual and collective consequences. The epitome is designed as a linear set of connecting stories that reinforce the need for virtuous behavior. The main plot revolves around the teachings of the monk Samarasena as he enlightens King Simha and his beloved wife Lìlāvatī along with their progenies. By understanding the exploits of their own past lives and adhering to the Jain precepts, the king and queen along with their children and close attendants paved their path towards final liberation. The story begins as King Simha, inclined to grow spiritually, requests a religious debate between different traditions. Having been convinced by a Jain layman who was present in the event, the king then seeks deeper knowledge from a wise renunciate who proceeds to explain the basic thoughts of Jainism. By means of storytelling, he transports the court through

\footnotetext{
${ }^{5}$ Library
} 
space and time, to Kaushambi, where the monastic character Sudharman gives a number of sermons explaining the concept of liberation and how to attain it by identifying and stopping the influxes of karma. Each story is of a linear, straightforward nature and illustrates clear examples of what actions are considered virtuous and which ones ought to be avoided (Cort 2009, 5).

Many of these examples can be traced to older collections of Indic stories, yet their rendering in the LVS becomes quite interesting due to the deceptive simplicity of the language. The stories are very vivid and life-like, they are relatable and designed to generalize situations and elucidate bigger pictures. What I mean by this is that, different from Jineshvarasuri's Nirvānalīlāvaīkahā, Jinaratnasuri omitted much of the poetic language used to describe details and events, focusing on presenting a clear and graphic representation of relatable situations. The purpose of this abridgment is to generalize examples of piety by the allegorical use of a compact and straightforward language. Thus the representation of virtuous behavior takes a clear and central role and makes the literary piece a prime example when analyzing the representation of goodness and its relation to spiritual advancement in the human realm.

I relied on Bronkhorst (2011) and Appleton's (2015) work on Karma because I believe their research is key to better understanding concept as karmic debt and consequences as well as the role of destiny within karma 
ethics . Bronkhorst articulates the Jain theory of how karma keeps our souls rooted to the cycle of rebirth, which facilitates the analysis of its presence and influence throughout the Līlāvatīsāra. His work aids the exploration of underlying soteriological conflicts between the divisions of the community. Appleton's (2015) detailed description of the many pathways that a human soul can follow towards liberation in Jain and Buddhist literatures sheds lights on the Indian view of human potential in the spiritual spectrum. Her work details karmic influence on Jain concepts of rebirth and explores key observations regarding the collective desire to reach liberation. Most importantly, she accomplishes this through the examination of didactic literature: Her research on karmic bonds through multiple lifetimes as a key influence of a community's collective final goal is a scope through which the characters in the LVS can be better understood.

For a most effective unraveling of the story, I used Cort's (2009) review of Jinaratnasūri's work against the Richard Fyne's translation (2005). His article examines the main characters of the narrative as literary devices. It presents a helpful list of some of the most important Kharataragaccha monks in the late thirteenth century along with a description of their own contribution to the vast Jain literary culture. My analysis of the literary themes and underlying significance of the language and style of the text follows Pollock (2016), who contends that we must take the location and historical period in which it was composed into account. Kelting's (2009) work then, served as a 
base when exploring the different layers of agency laywomen are ascribed within the Jain community. Although contemporary, her work addresses how standards for laywoman's virtue are often more highly regulated or subject to different quality than those of men.

What becomes of crucial importance and, thus, must be kept in mind when dissecting virtuousness in the Līlāvatīsāra, is that the definition of virtue as it is understood by western scholars who focus on Indian didactic literature needs to be revisited. The role of karma in these stories and its relationship to the exertion of violence creates an underlying hue of anthropocentrism that grants humans a much higher value in the Jain spiritual hierarchy. Thus, the inclusion of both fate as a totally independent phenomenon and human agency as not only existent but often actively working based on its own set of rules, creates an intricate web of behavioral catalysts that force us to rethink the ethics systems that could effectively be applied to this study. Lastly, because of the deliberate illustration of particularly limited female archetypes, women's agency in this text is restricted at best. The text places their role as secondary when directly in comparison to that of their male counterparts.

So, in order to untangle all of these ideas I have organized the project within four chapters. The first chapter will briefly discuss various story selections from the Lìlāvatīsāra which will be accompanied by my own translation of the 1983 Sanskrit rendering edited by Harivallabh Chunilal. 
There I discuss the significance of the chosen excerpts, the use of language and of important tropes. I also rely on R.C.C. Fynes' translation which helped to clarify many of my grammatical quandaries and offered a remarkably delightful use of language. As I delved into the text I focused on the use of allegory, descriptive vocabulary as well as the implementation of underlying lessons expressed through the rendering of the different tales.

The following two chapters address various concepts of virtue and its relationship to karma, fate and human agency respectively. I first explore the role of virtuous behavior in didactive narrative and suggest a different way of analyzing goodness as it presents intrinsic and extrinsic characteristics throughout the chosen manuscript. Regardless of its natures however, both goodness and virtue are often associated to karma and fate, which at the same time are bound to Jain concepts of human agency. I also include a brief analysis of translation and storytelling issues that affect the way in which we understand the different layers of significance narratives often convey. By linking all of those concepts together and using Queen Līlāvatī's selections as support then, I argue for the need to understand Virtue as the abstract value that decides whether violence can be both exercised and justified.

The fourth and last chapter then applies all of the previous concepts to the analysis of female archetypes illustrated in the text. Here I compare female and male characters and argue that, beside the difference between intrinsic 
and extrinsic portrayals of good, virtue itself takes a dual nature. This is represented as female virtuousness is often linked to family values, obedience and piety while male virtue is linked to spiritual maturity and growth, becoming the norm and most predominant idea. 


\section{CHAPTER I}

\section{The Lìlāvatīsāra and its Translations}

\section{I.I Didactic Tales and Their Significance}

To start, I believe it is important to mention the significance of this text as I believe it was effectively made for a very specific audience. Different from other poems, this singular redemption of Jineshvarasuri's Nirvānalīlāvaīkahā uses a very direct and clear language. The stories focus on the consequences of immoral behavior and often times, ontological theories appear as secondary. What I mean here is that religious tropes appear in the background while earthly/terrestrial lessons are at the spot light. Spiritual motifs in the Lìlāvatīsāra seem to be portrayed as something understood by the audience, which, based on the topic of most tales, was the Jain community. Not the elite or monastic groups but the laypeople whose scholastic capabilities were limited at best. This manuscript is not concerned with Jain elite philosophy or monastic rules, its instructive role however occupies quite an interesting and influential place in the identity building process of the lay community.

Virtue and good behavior as methods through which Jain practitioners could reach Moksa are very important as far as this manuscript is concerned, yet these concepts are not as imperative when delving into Jain ontology and karma ethics. Why is virtue not only immensely highlighted here but also prioritized over all other concepts? I believe that texts like the Līlāvatīsāra are 
meant to illustrate moral guides in a way that canonical scriptures cannot: They do not prescribe rules, they describe situations in which rules must be applied and focus on the consequences of such applications. The concepts of Virtue then as it relates to accepted uses of violence within these stories do not only convey the previously discussed message but with it, tell the story of how communities evolve and change throughout the centuries.

This poem is composed of 21 Cantos or sections, starting with the birth and early life of king Simha and followed by the different teachings of Samarasena. Some of these include the consequences of anger, the nature of pride, the consequences to addiction to the different senses and the final liberation of the different characters. Many of these cantos have intertwined sub-stories that serve to support or justify the main ideas they discuss. To illustrate/support my observations about Virtue as it is represented by different characters in this manuscript, I have chosen and translated a small selection of stories which will be discussed in the following section. Because many of the main ideas discussed in this thesis came out of the translating process, I believe it is important to delve into these examples before analyzing the role that virtue, karma and human agency play within the connecting web of narratives 


\section{I.II The Stories of the Lìlāvatīsāra}

\section{(i) The King and his Obstinate Queen}

The sub-story of the King and his Obstinate Queen is an excerpt of the Līlāvatīsāra's $2^{\text {nd }}$ canto: The Story of prince Ramadeva and the consequences of anger, violence etc. It occupies verses 199 to 220 of the 281 verses that conform the entirety of the canto and serves to justify the need to ignore a woman's request if such is ought to bring doom to the family or kingdom. In this example we are presented with the same amount of female and male characters. Women serve to represent bad or unvirtuous behavior while males represent good qualities such as piety, patience and common sense. I believe this sub-story is important because it manages to portray how female births are spiritually and morally below of that of their male counterpart whether it is in the animal, human or heavenly realm.

\section{(...)}

(195) "By command of the king, the prince must be put in jail. Lest this not be causelessly by the servants.

(195) Devanītiriyaṃ dhuryaḥ kumāraḥ pañjarodare|Rājñopacaryo rājyārtī kārṣīn mā’kāṇ̣aviḍ̣aram | |

(196) While prince Ramadeva is certainly worthless, let this be so! Lest this not ought to be done, oh dear lord, all will be destroyed!" 
(196) Rāmadevakumāre'pyanarthāgare tato'stu tat | Svāminnetat priyo bhūtvā maiva sarvaṃ vinīnaśat||

(197) [The king responds] "The good queen, Pryangulata who, afflicted by the sickness of love for the prince will not think agreeably of this in any way." (197) Śrīpriyańgulatādevī kumārasnehavihvalā | Etat prāṇaprahāṇe’pi kathañcana na maṃsyate||

(198) [The advisor says] "Disregard the queen, oh your majesty! This is ought to be done! By this deed, all that is good will expand to the king, kingdom and descendants alike.

(198) Śrīdevīmavadhīryapi kāryametanmahīpate | Yena devāya rājyāya prajābhyah svasti jụmbhate| |

(199) Let this example be heard! There was this king who, having lost his horse in the forest, walked, dismounted from the stable.

(199) Śrūyatāmatra ḍ̣șțāntaḥ ko’pyāsīt prthivīpatị̣ | Vane so'śvahṛto’yāsīdavarūDhasturańgamāt| |

(200) While he rested for a moment at the bottom of a Banyan tree, at the edge of a lake, a maiden from the underworld appeared.

(200) Sarastīre vațatale yāvad viśrāmyati kṣaṇam | Saraso nirgatā tāvat kācit pātālakanyakā || 
(201) She turned into a female snake in the very sight of the king, and at that instant, from a hole in the tree, a male snake appeared.

(201) Rājñaḥ paśyata evāsau sadyo’jāyata sarpiṇī | Vaṭakoṭarataḥ sarpo gonasaśca viniryayau | |

(202) They both engaged in intercourse and were struck by the whip of the angry king. "You abuse (your status), You two are doing a wrongful action in front of me!"

(202) Tau ca dvāvapi remāte rājñā kruddhena tāḍitau | Kaśayā re durācayau kurutho'karma matpurah | |

(203) Having been separated, the big male snake got lost in that same banyan tree and, (she) who was inexhaustible, (disappeared) in the lake. And a curiosity was born in the heart of the king.

(203) Viyujya gonaso nașțas tatraiva vațakoțare| Anyā sarasi rājñaśca hṛdyajāyata kautukam | |

(204) By tracking the footprints of his horse, (the king) reassembled with his troops and along with them (he) reached the city. (There) a huge festival happened.

(204) Rājño'śvakhuramārgeṇa sainyenātha sameyuṣā | Sārdhaṃ nṛpạ̣ puramprāpa jajñe vardhāpanaṃ mahat|| 
(205) Having dispatched all surround ministers, in the evening the great lord took rest in (his) chambers by his beloved wife.

(205) Vișrjyāmātyasāmantān pradoṣe vāsaveśmani | Viśaśrāma mahadevyā saha sarvaṃsahāpatị̣ | |

(206) In the underworld, the goddess having returned to the presence of her husband, said: "Husband, today, in the lake, (someone) attempted to conquer me.

(206) Sā ca pātāladivyaśrī parāptā patyurantike| Ākhyad devādya sarasi majjitum prāptavatyaham | |

(207) (And then) being solicited by him, I returned after being struck with his whip" He, enraged arrived at the time the king had awoken.

(207) Amunā prārthitā rajñānicchantī kaśayā hatā | Sa kruddha āyayau yāvat tāvad bhupạ̣ prabhudya sạ̣ | |

(208) Oh, he narrated the story to the queen, from beginning to end and at that time, the God becomes desirous in favor with respect to the king.

(208) Rājñyai taḍāga vṛttāntam āmūlāntam acīkathat | Sa ca devastadā kāmyaṃ saprasāda nṛpopari||

(209) Then the king, tending to the maters of the body and mind the God manifested (to him) and paid salutations. 
(209) Tatah śarīracintārtham uttasthau pṛthivīpatị̣ | Pratyakśībhūya devo’vag rajño svāgamakāraṇam ||

(210) "Oh king! From hearing your allegations, I have become satisfied, select a boon!" The king responded: "Grant me the understanding of the language of all beings."

(210) Tvaduktiśravaṇād bhūpa tubhyaM tușțo varaṃ vṛnu | Bhūpo'vadat sarvasattvabhāṣāvijñaṃ vidhehi mām | |

(211) "So let this be! (Yet) death (awaits) you in the telling to another." Thus, (after) the boon, having been given to the king, the god went away to his own home.

(211) Evamastu paramanyasyākhyāne mṛtyureva te| Evaṃ rajñe varaṃ datvā devaḥ svāpadam āsadat||

(212) One day, while the king holds a pot and the queen puts cosmetics on herself, a house lizard tells her husband: "Bring me those scented cosmetics"

(212) Pātrabhṛtyanyadā devyām śrībhūpe svaM vilimpati |Ānayāmuṃ me'ńgarāgam patimūce gṛholikā||

(213) He said, "I will not go get killed". Again that is repeated. The king laughed (at it) and the queen said: "By what cause do you laugh?"

(213) So’vag māryesmi nāneșye muhustāviti jalapatạ̣ | Rājāhasad devyuvāca hasitaM kena hetunā|| 
(214) The king explains thusly yet the queen insists. He says, "There is danger in the telling" to what she who is a fool, replied "Speak!"

(214) Rājākyadevameveti devyūce’vaśyamādiśa | Rājoce’pāya ākyāne brūhityevāha sā kudhīḥ | |

(215) Having piled woods outside, the king, sitting on an elephant along with (his) queen, gave gifts to (his) followers as he went around the city.

(215) Bahiścitaṃ kārayitvā devyā saha gajasthitah | Dānaṃ dadānạ̣ saparīvāro bhūpaḥ purān nirait | |

(216) Then a female goat solicited her husband for a plant on the ledge of a deep well. He said: "Oh woman! I am not to obtain (that)!" to what she replied: "Then I am not your dear (any longer)".

(216) Tadā chāgyāyāci bhartāndhakupatațavallarīm | so’vadallātumīśe na soce tannāsmi te priyā||

(217) The buck replied: “ Am I like that king, that (being able to) unite with another queen, is ought to die because of a foolish one? I am not to die over that, without you, there will be another." The king thought "Even that one (goat) is aware of that (which) I am not!"

(217) Chāgo’vadat kim anena sadṛ́soham mahībhujā| yonyarājñīsambhavepi mriyate'syāH kṛte mudhā| | 
(218) The king turned around and became benevolent. A queen is indeed to be admired, but not if the kingdom is in danger.

(218) Paśustdeṣa nāhaṃ tvāṃ vinā’nyā bhavișyati | Rājñācinti yadeṣo'pi jānātyetadahaṃ na hi| |

\section{(...)}

\section{(ii) The Story of Vasundhara}

The story of Vasundhara is the first example given by Sudharman in the $3^{\text {rd }}$ Canto of the LSV: The Nature of Pride and Falsehood. The actions of this man serve to point out the consequences of jealousy, mockery, and falsehood as his soul travels through a number of hellish lives and low births as the consequences of his unvirtuous behavior and regrettable deeds. This story occupies verses 21 to 117 out of the 278 verses of this canto and depicts a very detailed description of the punishment methods utilized by the town's people in regards to different kinds of mischiefs. The language used in this excerpt is quite beautiful given that Jinaratna tastefully describes the judgement and punishment of Vasundhara as a list of events meant to mock the false priest: Because the significance behind these punishments is simply described and not explained, it can only be assumed that information of this kind was common knowledge to the original audience. 
This story also describes the unfortunate disentanglements of events between the main character, Vasundhara, and a protector Jain goddess. The actions taken by this deity in order to defend the Jain Order become rather polemical when taking the concept of Virtue and the female representations of such into account.

\section{(...)}

(80) Existing under false conceptions, he became jealous of the virtuous ones who (practiced) a multitude of joyful meditation and tapas.

(80) Jātyā kulena śīlena tapasā dhyānamudrayā | Mithyābhimānī jajñe'sau guṇināM guṇamatsarī| |

(81) He who is conceited, with the one wealth of being compliant to false views. In that manner (he) is served by a false crowd and (only) thinks on his own hypocrisy.

(81) Mithyābhimānaikadhano mithyāvadāvaśaMvadạ̣ | Tādṛńmithyājanaiḥ sevyah svabakaM manyate'sakau | |

\section{(...)}

(101) At midnight, Vasundhara is requested by a goddess, whose body is splendorous. (She), unmoved, uttered to (he) who was lustful.

(101) Niśi śāsanadevyātha divyastrīrūpayā rayāt | Vasundharo'kṣobhī lubdhạ̣ prārthako bhaṇitastayā| | 
(102) "As a giver of wealth, ask and by means of a spell and nothing else, I can give the people wealth by daybreak."

(102) Vaśyā vayamudīciva dhanadasya parasya na | Dhanaṃ janān prage'bhyarthya dāsye manyasva tat priye | |

(103) Having said (that), he, engaging in (sexual) union with she who became a female dog, like a dog (himself) became impaled and, in that manner, at once he could not uncouple himself.

(103) Ityuktvā samprayuktaḥ sa saramībhūtayā tayā | Śvavat tayā kīlitaśca tathāsthān na vyayujyata| |

(104) $(\mathrm{He})$ in this manner was noticed by citizens and exposed to the whole town. Now, the goddess became absent and (so) the foolish one thought:

(104) Prage pauraistathā dṛșțo vigupto’sau pure'khile | Tiro'bhūd devatā sātha sa ca dadhyāvidaṃ kudhīḥ| |

(105) "This was done by Svetambara monks. If I am not to repay with destruction I am not a man and my life is impotent."

(105) Śvetāmbarairiti kṛtaṃ kṛte pratikṛtim na cet | Karttāsmi tannāsmi pumān niṣpalaṃ jīvitam ca me | |

(106) Then, having kindled a fire to burn hips of cow feces (around) the resting place of the monks at midnight, the wicked one accomplished sleep (yet) was noticed by (some) guards. 
(106) Sādhvālayaṃ tato dagdhum agnicchagaṇikākarạ̣ | Ardharātre prāpa pāpaḥ śayyāṃ netrā ca lakṣitạ̣||

(107) Having been bound by the guards, he is brought before the eyes of the king: "Oh lord, that (is the man) who ambushed the monks, talked (back) at learned men and went with the female dog.

(107) Baddhvā'rakṣaị sa rājño'gre darśito deva yaḥ purā | Sadhūn upādravat sūrīnabhyācakhyau śunīmagāt| |

(108) Then, this wicked one got caught as he burned the resting place of the Sadhus. What should be done to him, oh lord?" The king said: "Let him be ceased!"

(108) Sādhvālayaṃ dahan so’tha labdaḥ pāṣaṇḍapāṃsanaḥ| Kriyatāmasya kiṃ svāmin bhūbhujoktam nigṛhyatām | |

(109) Then, with black ash smeared all over his limbs, his own infamy personified is thus restrained in his own umbrella of falsehood that is like a broke winnowing fan.

(109) Tato maṣyā viliptāńgaḥ svāpakīrtyeva mūrtayā |

Sūrpakhạ̣dacchatrakeṇa mithyātveneva saṃvṛtaḥ || 
(110) With garlands of leaves from the Vilka tree ${ }^{6}$ and, having been decorated with a frontal sectarian mark with ingredients of red arsenic, (Vasundhara) was procured after like a corpse stumbling within the walls of a vehicle.

(110) Karavīrasrajā bilvamālayā dhātupuṇDrakaih | Rathyācīraiśca kugateh kațākṣairiva bhūṣitaḥ| |

(111) He, in light of all of his bad actions, deaf by his own dirty nature, was placed upon a donkey who was (both) dirty and earless.

(111) Akarṇo malinātmaiṣa ityakarṇe malīmase |

Rāsabhe'śubhatatkarmarāśibhe cādhiropitah ||

(112) The town's Adindima drum was played and so the proclamations "Enough with this sinful action!" and "A wicked man is displayed (here)" are extraordinarily uttered.

(112) Anenedaṃ kṛtaṃ pāpamiti pāpo vigopyate | Ityuccairghoṣaṇāpūrvaṃ purovāditaḍiṇịimạ̣ | |

(113) Wise man saw (that) at that time, with politeness and compassion "The great crimes become ripe"

(113) Tapasvino'muṣya mahāpāpamatraiva paktrimam | Babhūveti sānukampaṃ dṛștạ śișțatamairmuhuh | |

\footnotetext{
${ }^{6}$ These leaves are regularly used to relieve stomach issues and dysentery.
} 
(114) "The sins of this bad person should thusly be shown" then, having been dragged around the whole town,

(114) Durātmano'sya pāpasya pāpaṃ syāddarśanāpi hi | Iti paurairninyamāno bhramayitvākhile pure ||

(115) The corrupt one, along with the entirety of his evil deeds, is led by the king's men to the cremation site, like the Lord of the South (death) himself.

(115) Pradoṣaḥ saiṣa pākhaṇụī pradoșe rājapūruṣaih | ninye śmaśānamāsthāaṃ dakṣiṇādhipateriva | |

(116) He who was arrogant, being scolded by the guards while talking idly, bears death. The criminal is pierced and made to stand in a strong pole.

(116) Ārakṣakebhya ākrośan vilapannabhimānavān | Śūlāyāṃ mṛtyutūlāyṃ sthāpitaścaiṣa pātakī| |

(117) Now in hell for some time, he became one who lives in a hellish ocean. There, with a resounding amount of torment, he got rid of a bit of bad karma.

(117) So’thābhūdādyanarake nārako’mbhodhijīvitaḥ |

Tatrāsātavedanayākṣipad duṣkarma puṣkalam | |

\section{(...)}




\section{(iii) Buddhisagara and the Astrologer's Prediction}

The Sub-story of Buddhisāgara and the Astrologer's Prediction is part of the LSV's $3^{\text {rd }}$ canto: The Nature of Pride and Falsehood. This story occupies verses 33 to 64 and serves to illustrate the role of fate in the journey of a soul and prescribes methods through which to outwit one's ill destiny without changing the flow of events. The tale serves to augment Vasundhara's own story by demonstrating that one's own agency and decisions to behave in an immoral way are not directly related to a karmically dictated ill fate.

\section{(...)}

(33) In a city named Kshitipratishtita, the king Jitashatru had an advisor, the honorable Budhisāgara, who was an ocean of the prosperity (that is) intelligence.

(33) Kṣitipratișțitapure jitaśatrurmahīpatị | śrībuddhisāgaro mantrī sāgaraḥ pratibhāśriyām | |

(34) Subuddhi was his son. One day a fortune-teller who knew good and bad arrived by chance.

(34) Subiddhistanyastasyānyadā sadasi bhūbhujạ̣ | Āgannaimittikaḥ ko’pi tītānāgatavartivit | | 
(35) After approaching the king as a pupil that is ought to learn from a master's triumph, the diviner entered. The king proclaimed: "What do you know?" and he replied: "What was, what is and what will be".

(35) Jaya devetyathāśsiṣyopavișto bhūbhujoditah | Jñānaṃ kva te’vak sa deva bhūte bhavati bhāvini||

(36) Then the king's councilor stood close by. There, among the assembly, the king asked: "Of who is the future in the proximity that will be graceful or awful? Speak!"

(36) Tato'ntikasthe sacive sa rājñoce’tra saṃsadi | Kasya kiṃ bhāvi pakṣāntạ̣ śubhāśubhamudīraya | |

(37) (He) cautiously reflected on speaking openly. The king repeated: "Speak!" "The family of this (one) councilor will die in this manner in two weeks' time". (37) Vimṛ́śya jñānyavag deva prakāśam bhaṇyate bhaṇa | Saciveśakuțumbe’tra pakșāntarmārireșyati | |

(38) The king became (filled) with fear and ought to ask: "And from where would they come?" He replied: "Us ministers ought to be honored like a respectful son honors a father at all times, Sir".

(38) Sabhyaṃ bhūdhavo'vādīt kutạ̣ sā so'vadat prabhoh | Mantrī nạ̣ pitṛvan mānyo nāpamānyaḥ kadāpi bhoḥ | | 
(39) "Oh knower! Stand up! Having taken your knowledge, do not stand here for a moment (longer)." Was said by the king. (He), together with his accurate knowledge, stood up.

(39) Jñānin svajñānamādāyottișțha tattișțha mā kṣnam | Rājñetyukto nimittajño viṣaṇnạ sahasotthitạ̣ | |

(40) The advisor's friends ought to strategize, and his enemies ought to be wishful but the minister, from the corridor of the king's fine palace, went to his own home.

(40) Viṣedumantrimitrāṇi tadamitrāśca pipriyuh | rājāntaḥ saudham adhyāsta mantrī tu svagṛhaṃ yayau | |

(41) The minister, having privately invited him [the diviner], asked about the makings of the ill luck. (The sage) casually said: "Oh minister! (It's) Subuddhi, your son.”

(41) Mantriṇā guptamāhūya pṛștơrișțasya kāraṇam | Naimittiko’vadan mantrin subuddhistava nandanah | |

(42) Having begged the knower and having kept him in check from speaking to no other, the minister, sending him forth, invoked the son.

(42) Satkṛtya n’ānyasya kathyamidamityuparudhya ca | Jñāninaṃ vyasrjjan mantrī tạ̣ ca nandanamāhvayat| | 
(43) "Oh dear! The decay of our family caused by you has been casually spoken of. Speak! By the performance of what methods are we ought to disregard this?"

(43) Vatsa naimittiken'oktastvannimittaḥ kulakṣayạ̣ | Tadbrūhi kena vidhinā vidhị̣ pratividhīyatām ||

(44) "One is to renounce for the sake of the family. Having been reminded of that moral conduct of yours, let that be onto me indeed. Let auspiciousness everywhere around the family."

(44) Tyajedekaṃ kulasyārtham iti nīterbhavadgirā | Nāmaśeṣī bhavāmyastu kulasya paritạ śivam | |

(45) "Son, you take what I say, if not, who will that auspiciousness affect? Let the binding of the knowledge of the $4^{\text {th }}$ quadrant of the soul ought to see us from death.”

(45) Vastādhase madvacaścenna kasyāpyaśivaṃ tadā | Turyabuddhyā pratibaddho vidhiștagamagekșatām | |

(46) "Whose would the giving of these words (come from) if not from you? Father, then, by the power of my breath and the arrows of intellect our fate is to be averted.

(46) Tvadvacastāta nādhāsye kasyādhāsye tadā nanu | Matprāṇairatha dhībāṇairdurvidhiṃ runddhi śādhi nạ̣ | | 
(47) Aha! My son! My child who himself (lives) for the prosperity of the family. Similarly, by this approach, that foaming misfortune will be surpassed.

(47) Sādhu sādhūditaṃ vatsa vatsala svakulaśrīyam | Evam evam upāyena tīrno'yam aśivārṇavaḥ | |

(48) Having made a spacious box (where) even the wind (could) not enter, the minister caused his son to sit along the gifts of water and fruit.

(48) Kārayitvorumañjūṣāṃ marutāpyapraveśanām | Mantrī tatrāsayat putraṃ sārdahanam jalaphalādibhị̣ | |

(49) Having been bound by an iron band and having used 8 bolts, having been lifted by a male and let to the king's palace, the advisor went to the king.

(49) Lohapaț̣airdṛ̣hhaṃ baddhvā tālayitvāṣțālakaị̣ | Pumbhirutpātyaa rātsaude nītvā mantrī nṛpaṃ jagau | |

(50) My everything is before you for you to watch (over), and to be protected by my own guards for two weeks. In that time, just as I stay in my own dwelling place, I will not come near you.

(50) Sarvasvam me tvaddṛșțagre pakṣaṃ rakṣaṃ svayāmikaị | Tāvat svāvāsa evāvasthāsye naiṣyāmi vo'ntike | |

(51) Then, (this) being accepted by the king, he in his own family refuge and having been surrounded by relatives and guards, who are heroes by the devotion to him alone. 
(51) Iti rājñāngīkṛte svaukodvārāṇi bandhubhih | Niyantrya veșțayitvā ca prakīraih svaikabhaktibhih | |

(52) And, in there, the minister, staying awake along with his family worshiped eve so loudly and stayed in to practice meditation on the dharma and then, in the $13^{\text {th }}$ day...

(52) Caityeșvarcāṃ vidhāpyoccaiḥ sakuṭumbo’tijāgarī | Dharmadhyānena mantryasthāt tataścāhni trayodaśe | |

(53)The king's house became chaotic. The minister's son Subuddhi, having cut a pigtail from Ratnavalya, the king's daughter, returned to his own abode.

(53) Rāsaudhe'bhūt kalakalo'yaṃ subuddhiramātyasūḥ | Ratnāvalyā rājaputryā veṇịn chitvā svadhāmnyhāt| |

(54) While crying, she whose pigtail was cut, having gone to the king, commenced to speak to her father: "I was desired by him, who cut my braid as I refused".

(54) Rudatī sā chinnaveṇirgatvā rājñe'bhyadāt pitạ̣ |

Prārhitāhamanicchantyā chinnā venirmamāmunā | |

(55) The king, who was angry but self-restrained, was made known by Mohila, who was depraved among the ministers: "Long live the descendants of the king.

(55) Kruddho’tha Yamavad rājā vijñapto bhrașțmantriṇā | Mohilena ciraṃ svāmī jīvantyāyurbalāt param | | 
(56) In that way, I know that, that minister has been bad from the beginning." Then, the king responded: "That awful one is to be restrained in chains".

(56) Yaccakre mantryasau pāpastadahaṃ vedmi mūlatạ̣ | Atha rājñā sa evoktaḥ pāpo’sau srānnnigṛhyatām | |

(57) Then, along with his guards, he hastened towards the minister and became fixed on his bodyguards. The minister, by (means) of a dear, good friend wished to inform the king:

(57) Tatạ̣ sasainyaḥ so'dhāvan mantrisainyaṃ ca sajjībhūt |

Subandhunātha suhṛdā mantrī bhūpm vyajijñapat| |

(58) "Oh good lord of mine! On this day, like the medicine before a meal, give me an audience (and) by this, my entire property goes into the royal treasure and does not go anywhere else.

(58) Prāgbhaktyaivaiavāraṃ me susvāmin dehi darśanam | Sarvasvaṃ me yena yāti rāṭkośe yāti nāntarā||

(59) The king, in delight, restraining his own men went (along) with them. The minister then, pried the box open before the kings very eyes.

(59) Rājñā raṇe nișiddhe’tha svapuṃbhirgarbhito gatah | rājñạ̣ samkṣaṃ mantrī tāṃ mañūṣāmudaghāṭayat | |

(60) Then, inside it, the king, minister and guards saw Subuddhi, the minister's son, with scissors and a pigtail in his hand. 
(60) Tatastadantaḥ praikṣanta kṛpāṇīveṇipāṇikam | Rājā mantrī yāmikāśca subuddhim mantrinandanam | |

(61) The minister said: "The guards (must) have (had) a transgression". They responded: "Not even from eagerness!" The king amazed indeed (asked): "What sort of sorcery from the minister is this?"

(61) Mantryūce yāmikakṣuṇam tepyūcurna manāgapi | Rāțvismitạ̣ smāha mantrinnindrajālamidam kimu | |

(62) The minister replied: "Whether by fate, by god or a demon, whether unpleasant or convenient, it (happened) before your eyes.

(62) Mantryūce deva daivena devena dānavena vā | Pratikūlamidạ̣ cakrenukūlaṃ tu prabhordṛ́sah | |

(63) The wise councilor properly surrendered to the kings saying of "Speak of that!" "The shield of intellect was (there),oh king! (yet) so (was) an unyielding fate”.

(63) Tattvaṃ brūhīti rājñokte yathāvaddhīsakhobhyadāt | Dhīraḍḍanam dhṛtạ̣ deva dhāmnāshkalihatirvidheh | |

(64) The king, agitating his head many-fold and in secret, bestowed the honorable councilor with power by means of a shining quest.

(64) Dhūnaṃ dhūnaṃ śiraścitrād rājñā śrīsaciveśvarah | īśvaratvaṃ paraṃ ninye canframaulipradāntah | | 


\section{(...)}

\section{(iv) The Story of Yashomati}

The story of Yashomatī, which occupies verses 118 to 182 of Līlāvatīsāra's $3^{\text {rd }}$ canto narrates the fate of Vasundhara's soul after it burns some bad karma as a hellish being. This story illustrates the consequences of lust, deceit and pride and portrays a rather polemical relation between karmic consequences, human agency and the influence of inevitability in the journey of a soul. The language, as it is in most of these stories is straight forward and personal, yet also charged with religious significance.

\section{(...)}

(118) Then, one way or another, Vasundhara's soul came forth, impure by the filthy moss of that (his) remaining bad karma.

(118) Tatah kathañcinnirgatya sa vasundharajīvakah | Tattādṛkṣakarmaśeșajambālamalakaśmalạ̣ ||

(119) In the country of Magadha, of which reactions about its obscurity (occur) often. In a village called Gorvara, which is filled with a bad and wicked multitude.

(119) Pāpațhyamānamagadhāgādhe magadhamaṇḍale | Durvārapāmarākīrṇe grāme gorvaranāmani| | 
(120) The Brahmin Yajnadatta, who performs (proper) sacrifices of the six karmas, he who is diligent in the sciences.

(120) Șațkarmakarmațhasya śrīvidyānāṃ pāradṛ́śvanaḥ |

Niștitāśeșayajñasya yajñadattadvijanmanaḥ | |

(121) With a wife called Radha, they rose up, bearing a daughter called Yashomati.

(121) Rādhāsamabhidhānāyāḥ patnyā udarakandare |

Keśavavāmanagadābhṛnmādhavasutopari| |

(122) Who was brought forth from the womb during the second month of spring, under the constellation of the mace bearer, having lustrous hair, grew up around the joyful hearts of her father and brothers.

(122) Yaśomatīnāmadheya putrītvenodapadyata | Sāvardhata kramātsārdhaṃ pitrịhrātṛmanorathaị̣ | |

(123) This very young woman married the boy Somadeva for love, who, by the happiness of all, was like the god of love (himself).

(123) Bālikaivātivāllabhyāttairmahena mahīyasā | Sā vāmadevatyksomadevena pariṇāyitā||

(124) And after the wedding, Oh! Somadeva, with exceedingly curving pain, dies like the moon id a vanishing night. 
(124) Vivāhānantarāhe ca śulādan̉kena bhūyasā | Somadevaḥ soma iva niśāśeșe'stamāsadat||

(125) Then, she lamented for a long time and was consoled, in any case, by her father and brothers, whose faces were submerged by the bursting of tears.

(125) Tatah pitṛbhrātṛmukhairaśruplāvitadṛnmukhaiḥ | Ciraṃ prarudya rudatī sā kathañcana dhīritā||

(126) "The marriage of a daughter (should be) with a family who is bound with prosperity and by the best of good wealth. All of that, oh my child, was prepared by both fathers.

(126) Kulyena dhaninā yunā vareṇa subhagena ca | putryudvāhyā pitṛbhyāṃ tatsarvaṃ vatse'dhikaṃ kṛtam | |

(127) However, that divine event broke into a hundred pieces by a mocking fate. So let the wise ones and Suvrata Acharya know about this calamity.

(127) Paraṃ tadaiva daivena sahasā śatakhạ̣ditam | Daivaṃ ca suvratācāryābhyākhyānaṃ budhyatāṃ budhāḥ | |

(128) Oh daughter! For the sake of appeasing this fate, stay virtuous and give yourself to worship and austerities." Upon joining (a group of wise men) she did (exactly) that.

(128) Putritaddaivaśāntyarthaṃ śîlaṃ śîlaya dehi ca | Tapasya vaśyaya svaṃ cetyukte taiḥ sā tathākarot|| 
(129) Then all of her brothers, brother's wives and even fathers, were ought to please Yashomati like (they would) a family Goddess.

(129) Tatạ̣ prītyā pitṛbhrātṛjāyā yaśomatīm | Sarvepi prīṇayāmāsuḥ kuladevīmivānvaham | |

(130) And she, by the power of her virtue, humiliated the wives of her brothers who do not speak against her from the distress caused by their husbands and mother in law.

(130) Sā ca śīābhimānena nyakkaroti prajāvatīḥ |Śvaśrūpatibhayāt tvetā na tāṃ prati vadantyapi||

(131) Furthermore, she who in the burden of her puberty carried ideas of trembling desire, oh! She indeed became acquainted with a cycle of bad behavior (involving) herself and her own body.

(131) Atha sā yauvanabhare manmathonmathyamānahṛt | Svayaṃ svānge kuceșțāstāścakre yā veti saiva hi||

(132) On another day, Sadhvis who were gifted by virtue and modesty, who by (knowledge) of the great truths and (practice) of tapas, become the way to deliverance in the ocean of life, together, arrived there.

(132) Anyedyuh śîlaśālinyo mahāsatyastapodhanāḥ |

Bhavābdhinistārataryaḥ sādhvyastatra samāyayuh | | 
(133) There, at that time, on account of her own improper (action), by the birth which happened a long time ago, arrogance and false speech became abundant in her.

(133) Atrāntare purābhyāsājjātisvābhāvyatastathā | Abhimāna mṛsābhāṣe bhṛ́sam tasyāṃ vilesatuh | |

(134) Having pointed at all the nuns, she who is awful, declared to her girlfriends: "From where in their unwanted coils does virtue (reside)? Those who find satisfaction is the back of town.

(134) Tata udṛśya tāh sādhvīḥ sā pāpākhyatsakhīḥ prati | Śìlamāsāṃ kuto'niștabhujāṃ grāmapurāntare | |

(135) Those whose diet is of bulbs, herbs and fruit, who ought to be glad by the one difficulty that is living in the forest. How is it that those never abide by their virtue?

(135) Kandamūlaphhalāhārā vanavāsaikatatparāḥ | Khaṇdayanti yadā śîlaṃ tadāsāṃ kā kathā nanu| |

(136) The girlfriends said: "How is it that their brilliance is not gone by the changing of their bellies (then)?" She responded: "There are multiple truthful remedies to pluck out and cause a fetus to fall.”

(136) Ākhyan sakhyastadetāsāṃ kukșirvikriyate na kim | Soce’neke santyupāyā garbhaśātana pātanāḥ|| 
(137) "She is certainly unvirtuous" Their thought in their own hearts. "How else could a harlot be aware of what (Yashomati) is otherwise."

(137) Nūnameṣā kuśîleti svahṛdā menire’tha tāḥ | Anyathaitatkathaṃ kāraṃ bālaraṇḍ̄vabhudyate | |

(138) Oh! Her inappropriate actions would not perish even after the stories of the auspicious Subrata the blessed one. The gap in her karma increased.

(138) Śrīmatsuvratasūrīndrābhyākhyānāśubhakarmṇi | Akṣinnepi hi sā karmāntaramevamupārjayat| |

(139) And, two goddesses from the divine order (said): "This awful one speaks fearlessly. The rendering of this will fall on that head of hers.

(139) Dadhyau śāsanadevī ca pāpaiṣā vaktu nirbhayam | Acirādetadetasyā mastake pātiyișyate | |

(140) One day, the son of the chief of the community whose name was Mayaraja, moved from the farm to the pond near the village and went for the sake of drinking water.

(140) Anyadā grāmakūṭsya māyārājābhidhaḥ sutạ̣ | Kṣetrād grāmasarasyāgāt payạ̣ pānādihetave | |

(141) And then, the female slave of the village's head chief Ramadeva, with a pot, also went there. And, having been known by him that it was lonely, he begged her for intercourse. 
(141) Tadā ca rāmadevasya grāmeśo ghațadāsikā | Tatrāgādvijanaṃ jñātvā tena sāprārthyamaṃsta ca| |

(142) Having engaged in intercourse with her, in a temple at the edge of the creek. She drank water from the river and semen drops fell during the act.

(142) Saraḥ pālyā devakule tayā raṃtvā sarasyasau || Ācacāma tasya retobindavah salile'patan | |

(143) And, both of them went their (separate) ways. Then, because of her instability and the bad fate (foretold) by the adverse goddesses, the brahmin lady Yashomati (approaches) the creek.

(143) Gatau ca tau yathāsthānamatha durdaivavaibhavāt || Devatāpratikūlyācca brāhmaṇī sā yaśomatī||

(144) Having cleansed her period blood, she wondered (around) and arrived there to that very region of the creek where the sperm was, and the remains swiftly floated around the water.

(144) Ṛtusnātā bhramyamāṇā samaittatra sarodiśi || Yatrādhvastā bindavaste taranti salilopari | |

(145) She even drank it, and (when) that sperm filled water entered her nether regions, she even rejoiced around from pleasure, not being aware of anything.

(145) Sāpyācāmattatra te ca binduvastadbhage'viśat |

Sāpyānandāccamaccakre niścikāya na kiñcana|| 
(146) In the disregard of some days, she wondered: "Huh, my stomach is turning droopy, what kind of water-belly (sickness) is this?

(146) Kiyatsvapi dineșveșā vyatīteșu vyacintayat | Jațharaṃ jarațhībhūtaṃ tatkimetajjalodaram | |

(147) But the throbbing inside did not feel like (a belly-ache) and she tried to (accomplish) the destruction or abortion of the fetus. Yet that fetus, plastered like hard cement, did not fall.

(147) Naivaṃ kiñcit sphuratyantastato garbhasya śātanam | Pātanaṃ ca cakāraiṣā nāpatadvajralepavat | |

(148) So then, because the symptoms of a belly (shaped) like an onion, oh! The impossibility to conceal her blossoming (became evident) to all.

(148) Atha garbhasya lasunasyeva cihnāni sarvatạ̣ | Apahnotumaśkyāni tasyā hantojjajṛmbhire | |

(149) Her mother Radhika said: "Oh little daughter! What is this!?" She (Yashomati) responded: "Oh mother! This immense bad karma is not from this world.

(149) Mātrā radhikayā saiṣāpracchi vatse kimīdṛ́am | Sākhyanmātarnaiva tāvad duṣkarmedam mamaihikam | |

(150) But whether it is some bad karma related to another life (becoming) fruitful now, that I do not know. What do I make out of that tardy bad fate?" 
(150) Pāratrikaṃ tu yat kiñcidduṣkarmaivaṃ phalegrahi | tadaṃba naiva jānāmi mandabhāgyā karomi kim| |

(151) The mother responded: "Oh daughter! This bad karma did not come out of piety, it happened by one's own actions which are contrary to that of virtue.

(151) Mātāvocatvatse duṣkarmaihabhavikaṃ vinā | Na pārabhavikenaiva kevalena bhavatyadah | |

(152) Oh that stupidity of yours is (quite) clear. Dirt has been thrown on your own two sides of the family just like both banks of a river are stained from the impurity of the ground.

(152) Tanmūụhe hā tvayātyuccaih pātitaṃ svakuladvayam | Malīmasarasāveśāttaținyeva tațadvayam | |

(153) Then it was said by her to the mother: "If water-belly sickness is deceitfully spread about, that awful fetus can be dropped.”

(153) Tayātha bhaṇitā mātā cejjalodaradambhataḥ | Dāpyante parito dambhāstadā garbho galatyayam | |

(154) But I can (whether) die as death (overcomes) the fetus or live in bliss. Oh mother! Make it happen for me. My pathway is no other than you.

(154) Ahaṃ tu galite garbhe mriye jīiāmi vā śubham | Tan mātạ̣ kārayedaṃ me tvatto nānyā gatirmama|| 
(155) She listened to everything and made it known to her own husband who then showed the daughter to the doctor.

(155) Pratiśrutaṃ tayā sarvaṃ svabhartuśca niveditam |

Devarakșitavaidyasya so’pi putrīmadarśayat | |

(156) The doctor said privately to the noble lord "That belly is not indigestion". The brahmin, distressed, having bound (his hands) in an ananjali, said: "Do not speak to anyone!"

(156) Bhațtāayoce raho vaidyo garbho'yaṃ na jalodaram | Bhaț̣ạ̣ khinnơỡjaliṃ baddhvā tamūce'nyasya mā bhaṇīh | |

(157) And that was communicated by him to his wife in a secluded place. She reflected: "What am I to do about this?" (So) a deliberation was reached by both of them in secrecy.

(157) Bhaț̣inyāśca tadekānte tenoktam sāpyamanyata | Tat kiṃ kāryamiti channam mantrayete imau mithạ | |

(158) Secret deliberation (which) was strenuous for both of them since that belly of hers had in turn become known to the world.

(158) Mantracchannastayorāsīnna tasyā udaraṃ punaḥ | Loke’tha sā kuśîleti sphuṭitam pakkagaṇḍavat| |

\section{(...)}




\section{(v) The Story of Princess Durlabhika}

The sub-story of princess Durlabhikā occupies verses 72 to 83 of $4^{\text {th }}$ Canto's 410 verses. As this canto illustrates the consequences of hypocrisy coupled with theft, the sub-story works to better rationalize the need to abide by our place on earth: Dhana the merchant, is defended by his friends after being apprehended because of unvirtuous and treacherous business practices. After telling the king about how often business malpractices occur and how because of their inevitability, that were ought to be overlooked, the king who was very wise, responded with the following story:

\section{(...)}

(72) In the amazing gardens of Vasantapura (which) are like prosperity in the season of Spring. (There) was the great lord Jitashatru who (took) delight in protecting the earth.

(72) Śrīvasantapurārāme’bhūd vasanta iva śriyā | Jitaśatrumahīpālo mahīpālanalālasah | |

(73) Vasantashri, his queen, (was) a house of good womanhood (and) their daughter Durlabhika (was) rare like a wish-fulfilling vine.

(73) Vasantaśrīstasya devī saubhāgyaikaniketanam | Tayordurlabhikā putrī kalpavallivva durlabhā| | 
(74) And Dhayini, the daughter of a yarn weaver was her friend. And back from when they were born, the fostered an affection (towards each other) which was like gold.

(74) Tasyāśca dhāyinī nāmnī tantuvāyasutā sakhī | Tayoścāśaiśavajjajñe premahemam akṛtrimam ||

(75) "Oh friend! I am obstructed inside of this town, let your dear be my lover, let the union of (us three) be like a bharundha bird." Said the king's daughter.

(75) Sakhyantaḥ purarudhāsmi tat te rucyo'stu me priyạ̣ | yan no bhāruṇḍvadyogah syāt tāmityāha rāṭsutā||

(76) Then, the daughter of the weaver, who was in love with a crippled says: "All of us will not at all be found as long as we go to another town."

(76) Kauvindī sātha vaṇtena prasaktābhāṇi tena ca | Naiva jñāvāvahe yāvat tāvad yāvaḥ purāntaraṃ||

(77) It was uttered by her: "The king's daughter is my friend and (has) confirmed this decision. The cripple spoke: "She, let her come forth". So then, (the weaver's daughter) summoned the princess.

(77) Tayoktam me’stri rāṭputrī sakhyevaM dṛ̣hasaṃśravā | Kaṇṭho jagāda sāpyetu rāṭputrīm atha sāhveyat ||

(78) Then, all three of them set out together in the evening, from a house. There, in a distant hut someone recited a short hymn: 
(78) Trayo'pi te’tha saṃbhūya prodoṣe niryayurgṛhāt | Atrāntare mațhe kaścid agāyād gītakām imām ||

(79) "A Karnikara flower is not able to bloom [without] contact with water. Even if servants cause a comm otion".

(79) Jai phullā kaṇiyārayā cūyaya ahimāsayammi ghuțtammi| Tuha na khamaṃ phulleuṃ jai paccaMtā kariṃti Damarayāiṃ| |

(80) Having heard this, the king's daughter, whose intellect had become pure, thought: "Going (along) with the depravity of vile (people) is certainly not my place.

(80) Tāṃ śrutvā cintayāmāsa rājaputrī pavitradhīḥ | Hinā hīnena yātveșā na me yuktamidaM punah | |

(81) "Friend, I ought to procure my make-up (which) I have forgotten". Then, under this pretext, the princess, reaching her own house, was removed from those two awful ones who were gone.

(81) Sakhi bhūṣākaraṇḍ̄ me vismṛteti miṣād atha | Durlabhā svagṛhaṃ prāpa pāpau tau nirgatau gatau||

(82) But the king's daughter, she became encouraged and wished for a superior son of a king, thus belonging to kingly wealth.

(82) Rājaputrī tu sā pitrā rāṭputreṇa varīyasā | Udvāhitenābhūd bhājanaṃ rājyasampadām | | 
(83) If people like a weaver's daughter speak ill or behave immorally, that is ought to be accepted from the indigent. Unlike them, misfortune will affect the wealthy even if they have riches.

(83) Tad aho janā yadi kuvindasutāvadanītimādadhati nirdhanakāH| Tad ayaṃ dhano'pi dhanavānayanaṃ kurutāmutāvanipasūriva mā| | 


\section{CHAPTER II}

\section{Virtue in Didactive Narrative: Re-Defining Good and Re-Assessing Human Worth}

\section{II.I The Differences Between Virtue and Goodness as Rendered in Jain Medieval Literature.}

The concept of morality as a functioning principle that determines whether our actions are right or wrong is ever latent in our subconscious mind. There is a universal understanding of the codes of conduct one is to follow in order to reach our highest form, or spiritual peak. When we do focus on moral epistemology, however, and decide to break down the core of human intentions as well as the innumerable ways in which those are artistically represented, then we most likely adhere to virtue ethics or the deontological, eschatological, or virtue ethics as well as the respective normative rules they carry. Although these systems of analysis often prove effective, I believe, when it comes to the study of Indian religiously-charged didactic literature, either method becomes rather lacking on its own. I argue that Western typologies of ethics are inadequate when addressing the illustration of Jain virtuousness in didactic literature. Not only for the Jain community but for Indian people in general, the implementation of narrative as a way to convey socio-religious information is common. The instructive and interactive nature of these bodies of literature allow for an illustrated description of soteriological models. By utilizing 
archetypes that exemplify spiritual lessons, this literary style is not only able to exemplify the importance of accepting and following the right path, but it simultaneously conveys practical ways of applying such concepts within the community.

The volume of didactic literature collections that is yet to be translated is immense. This ever-growing number of narratives that often serve as a template for proper behavior do not merely exemplify the ethical models stated in formalized canon, it augments them by also illustrating how to identify and properly apply such guidelines. It is important to have in mind that not only for Jains but for Buddhists and Hindus alike, sacred texts are utilized in a very particular manner. Folkert states that, when transmitting words of sacred significance, the fact that sounds can be rendered through writing becomes spiritually irrelevant (Folkert 1993, 38-9). His research highlights that modern studies of canonical scriptures often focus on their written aspect and the rendering of such has de-emphasized the sacred value of sound itself. Oftentimes, these scriptures are memorized and utilized in ritual practices as the power of the sound is given the same or even more importance than the meaning of the words being recited. As Folkert very well explains, "By and large, Jains do not 'read' their canonical literature per se, either in a ritual or daily pattern. What they do use is a collection of excerpts, in the format of a missal. This collection, known as the Pratikramana Sutras (...) [which] form the major part of all the religious literature, or scripture, that the Jain 
layperson knows" (Folkert 1993, 92). This does not mean that Jain canon is exclusively oral but that there are limitations to how it is utilized in a social context.

Canonical texts in Jainism, as well as in many other Indian religions, involve the prescription of right behavior and the careful explanation of spirituality as it relates to a final goal. However, these texts focus on stating the rules and regulations that a community is to follow without leaving much space to exemplify such teachings. The Tattvartha Sutra for example which, due to its early existence and the nature of its content, is authoritative to Śvetāmbaras and Digambaras alike; it contains detailed information of the path towards final liberation, the nature of karma and rebirth and categorizes truth and virtuous behavior for both ascetics and laity. This text is used to build both the religious and the cultural atmosphere required for the community to strive, yet it becomes limited in aiding followers digest this knowledge. Narrative however, assists this process because it transmits information in a different way than these prior texts. Whether narrative is written with a religious end or not, the semantic meaning attributed to the words becomes more important than the sounds themselves, given that the significance is not within such reverberations but within the lessons being transmitted by (determining) the semantic meaning of a specific passage (Folkert 1993, 38-9). Didactive stories do not only contain rules and regulations 
but provide examples that allow practitioners to better place their everyday actions within a prescribed sense of morality.

Narrative is didactically effective on many levels. Whether in written form or as part of an oral tradition which does not necessarily require a high education level to retain and reproduce, the structure of narratives allowed for a more personal intake of religious teachings because they can transform highly complicated concepts into topics of a more mundane nature and become relatable to the community. They allow for the audience to arrive at conclusions on their own and do so by making the characters relevant and the consequences of their acts clear and explicit. Narrative is quite often utilized to emphasize the importance of values such as virtue, moral behavior and, religious piety. The richness of each story however, and the intricacy behind what at first sight may seem like a simple, linear narrative, puts the idea of virtue as intrinsically connected to a unpolluted human soul in a polemical position. The often-contradictory examples of moral behavior as they are rendered in literature require us to design a new hybrid theoretical framework in order to better understand their function as moral shapers of the whole community.

In order for us to delve into this discussion, we must first address the concept of virtue itself. Social structure and a sense of correct behavior are necessary in any functioning society. Either from an eschatological or 
deontological perspective, acting virtuously implies behaving in a way that consolidates a community's definition of good. This general understanding of virtue is one not only in need of recognition by that group but must also be able to justify moral behavior as they understand it. I believe that these concepts become much more complicated through the rendering of Jain didactive literature because there, virtue and good are not directly interchangeable. Because Jain narrative often prioritizes the importance of morality, acting virtuously is directly related to being good. Western scholars however find it a challenge to try to fit those two together. Attempting to understand the good versus bad behavior ratio a soul can experience while still remaining virtuous becomes easier if virtue and good are addressed as different entities.

In his book, The Nature of Goodness, Palmer (2010) strives to create a universal model to define and understand the nature of good. He presents a very interesting diagram in which his idea of intrinsic good and what it signifies to the human community is defined. He states that there is a universal design that can be effectively applied to people or events in order to identify their position along the morality scale (Palmer 2010, 24). To correctly apply his concept, one must have in mind the two major kinds of good, intrinsic and extrinsic. The former "expresses the fulfillment of function in the construction of an organism," meaning that it is relative to the specific needs of a creature; the later one, "found when an object employs an already constituted wholeness to further the wholeness of others," is closer to the basic 
core concept of virtuous behavior (Palmer 2010, 51). Still, one cannot exist without the other. Ironically, as Palmer develops his theory of intrinsic good, the connection between it and communal interaction becomes apparent. When he states that "goodness in its most elementary form appears where one object is connected with another as means to an end," he is highlighting an indisputable inherent connection between objects and individuals because intrinsic good, although exercised for one's own state of wellbeing, needs some kind of connection with an object, or another subject, in order to exist, and thus fulfil the conditions under which extrinsic goods can emerge. What I believe is important to take from this study is that virtue and our common definition of good are not equivalent or often interchangeable as far as their rendering in Jain narratives go. To be virtuous as an innate attribute of the soul becomes intrinsic while acting morally, while performing good deeds is extrinsic in nature. In this chapter, when I discuss virtue, I will be referring to Palmer's notion of intrinsic good, to the individual inclination to act upright that, whether motivated by spiritual forces or simply by social code, defines an individual's decision making as morally acceptable.

Now, I find it is not possible to consider anything or anyone intrinsically good without bearing in mind their cultural and religious background. As Bauman states, "the realm of truth is resituated from a transcendent space of foundations to the evolving nature-cultures in which we live" $(2014,76)$. To act virtuously, not only among Jains but in any religious community, is to act 
according to the community's sacred law. The Acaranga Sutra, as an important part of the Śvetāmbara Jain canon (Agamas), holds a sacred significance for the Jain community. It does not only cosmologically describe the soul's journey to moksha or a liberated state, which is an individual's final goal, but also defines suffering as the ultimate and unavoidable result of action. As far as early Jainism goes, avoiding suffering and liberating of the soul then depends on the shedding of all karmas (negative and positive) and that can only be accomplished by absolute inaction. Interestingly, this prescription does not leave much space for the exercising of good actions. Thus, the practice of virtuous behavior can expedite the process of enlightenment (Bronkhorst 2015, 10-1). Acknowledging virtuousness not only as a spiritual catalyst but as a model of exemplary social behavior argues against Jainism as a fatalistic system while still allowing for a belief in inevitability and fate.

\section{II.II Perpetuating Virtue}

Why then is shila given such importance within these texts? If the absence of Karma, both good and bad is a condition for liberation then, how is enlightenment attained by the exertion of optimal moral behavior? Why do we as humans emphasize the need for virtuousness in such detail? Jaini (1979) discusses a very effective method through which Jain literature articulates a souls' spiritual progress and how that connects to virtue. A human being can experience fluctuating bursts of spiritual clarity if their karma dictates so. 
When these momentary experiences happen, the individual often decides to follow the path that will get him/her to an eternal state of bliss faster. Jaini writes, "suppression or temporary pacification (upasama-samyakatva) does afford the aspirant a first glimpse, as it were, of the true nature of reality, and it gives him a taste of that bliss to which he will ever seek to return" (Jaini 2000, 221). I believe both Jaini and Palmer would agree that the human search for meaning, or the attainment of this moment of omniscience, catalyzes the desire to act virtuously. Palmer, however, does not believe that pure extrinsic good is humanly possible, because, as he argues, no human can perform a disinterested act without having some sort of agenda. He argues that whether good or bad, we do all with a subconscious goal in mind. To support this claim, he states, "when we thus accept self-realization as our supreme aim, we bring ourselves into seeming conflict with one of our profoundest moral instincts, (...) the claim to realize oneself and the claim to sacrifice oneself' (Palmer 2010, 152). These ideas of intrinsic virtue and selfless behavior, although sometimes proving contradictory, are by no means uncommon in literature; the topics of self-sacrifice and intrinsic desire to act virtuously are often paired up in narrative.

The story of Vasundhara in the LVS's third canto, "The nature of pride and falsehood," provides a good example of the previous statements (Jinaratnasūri 1983, 50-8). Vasundhara was a child prophesied to bring doom to his family. Because the proper protective rituals were performed, he did not 
affect his loved ones in any way. However, the entire family still found death in the arms of disease when he was just five years old. As he grew up in the guidance of the wrong company, he pretended to be a wise ascetic. When this did not satisfy him he started to slander and falsely accuse ascetics around him. In order to teach him a lesson, a Jain goddess appeared to him and, taking a beautiful human form, invited him to join her in sexual intercourse.

He, engaging in (sexual) union with she who became a female dog, like a dog (himself) became impaled and, in that manner, at once he could not uncouple himself. (He) in this manner was noticed by citizens and exposed to the whole town. Now, the goddess became absent and (so) the foolish one thought: "This was done by Svetambara monks. If I am not to repay with destruction I am not a man and my life is impotent"' (Bhayani 1983, 48).

Believing the Jain monks responsible for the whole ordeal, Vasundhara then set fire to their residence and, once found guilty, he was executed. If judged by canonical prescriptions of virtuousness alone, at least if categorized as a female laywoman, the decision making of the goddess in this story would be regrettable at best. However, in this story, her actions are not only undisputed but upheld and admired. In this specific example, the goddess' conduct was focused on defending the honor of virtuous Jain ascetics; she engaged in actions otherwise considered immoral for a greater cause thus her decisions become justified (Fynes 2005, 175).

${ }^{7}$ Refer to Chapter I for the full translation. 
Humans utilize narrative to perpetuate their most fundamental nature. In order to preserve these as part of their history and honor the present they use origin stories and educational tales. These accounts, whether preserved orally or scripturally, prescribe the socio-cultural environment of the individuals to which they belong to, thus allowing for effective analysis of the beliefs of communities at specific points in time (Hewlett 2010, 147). Religious narratives then become an effective organizing system that dictate meaning through our daily existence, we use these narratives as a tool to frame the world both as we know it and as we want to know it (Bauman 2014, 23). This effect which is part of the realm of value, contain what Cort (2011) refers to as implicit worldview assumptions, a systematic representation of values that seem to follow our own anthropocentric ideals. So then, as creatures that constantly disseminate that which signifies meaning, perpetuating the concept of virtue in Jain narrative becomes crucial. In the LVS Canto 6, "The Consequences of Greed Coupled with Abusiveness," Prince Kanakaratha was well educated and properly married while living in his father's kingdom (Jinaratnasūri 1983, 153-168). While he left the palace to visit the city and inspect the different merchants, bazaars, jewelers and houses, the prince's insatiable greed awoke. He asked his father to take away all of the subjects' surpluses along with their extra properties to invest in a greater army, which his father initially denied. After much insistence however, the king agreed with the prince's idea of tricking the feudal lords out of their land and riches. Having 
heard the news ahead of time however, the lords teamed up and executed the father while the prince barely escaped. This story does not only thoroughly describe the consequences of greed and ill-intent, it contains detailed descriptions of life in a royal court. It contains the customs of the community where the character resided, their economic traits and most popular practices, the duties of the people and the layout of their residences. Besides a wonderful depiction of the consequences of deceit, the narrative also tells us about the policies of the area, the political procedures and raises questions about the tension between kingship and filial relations.

To understand the evident reinforcement of virtuous behavior in this text, we must consider the social layer of the narrative as it emphasizes on moral behavior at a worldly or secular level. Religious belief served as a way to solidify a desired social structure and this is clearly reflected in religious narratives. The sub-story of Princess Durlabhika can help exemplify this. This story is part of a much lengthier tale describing the life of the merchant Dhana, belongs to the LVS's fourth canto, which deals with the consequences of hypocrisy coupled with theft. The princess is very good friends with the daughter of a weaver. This friendship was so dear to her that she decided she would marry any person her best friend chose. Dhayini, the weaver's daughter, was in love with a deformed man, which is a sign of a moral deformity (Day $1982,164)$. Because the princess loved her friend so much, se agreed to run away with them. However, by chance, she heard a recitation that stated how 
those of noble positions should not imitate the faults of those of lower rank. She realized her mistake and gave an excuse to the couple to safely return to her castle and eventually be properly married to a good prince. It is important to highlight this story because it does not only describe the consequences of pretense, it works as a tool for social order. The story works as a reminder of status responsibilities, yet it also presents an underlying negative description of the peasant. On two occasions the story justified improper behavior of poor people with the mere fact of belonging to the right (or shall we say wrong) class. The first time is when the couplet heard by the princess states that those of low birth shall not be taken as an example and that nobles ought not to follow the steps of the commoners. The second time is at the end of the story, when the king who judges Dhana states that dishonesty may be expected from a poor man but could simply not be justified if coming from a nobleman or wealthy merchant. The implication here becomes evident, thus supporting the need to analyze every layer of significance the text has to offer. Religious sentiments should fuel the desire to act virtuously and thereby maintain dharma. Thus, the importance of religious authority and spiritual consequences that are given through narrative efficiently solidify these institutions.

\section{II.III Virtue Prescribed for the Virtuous: The Abstract Value of a Soul}

Now another aspect that must be addressed when analyzing virtue is how the exercise of such varies in significance to who acts it out. Virtuous behavior is 
subconsciously defaulted to the human realm, thus reinforcing the special place mankind occupies in the Jain cosmological hierarchy. As discussed previously, in order for practitioners to reach a final goal, the shedding of all karmic residue must occur. However, karma can be good or bad, meaning that the particles of which karma is made of can increase or decrease because of whether we behave well or not. The solution to this issue cannot be other than total inaction of the body and mind. But where can a line be drawn between the extremes? That is, how can practitioners stay on the path to liberation while staying active in this world? The answer lies in the proper practice of ahimsa, or non-violence. To act virtuously then, means to act according to the prescribed methods against violence. Most traditions in India highly value the practice of ahimsa as a virtue. Jains, as part of this concourse, actually enumerate 432 different kinds of violence. They are subdivided into different categories which relate to one's mind, speech and body (Tähtinen 1976, 15). Although one would assume that Jains see violence and virtue as completely opposite, the relationship between them becomes much more complicated and harder to define.

Violence is only immoral when it is not prescribed within a specific situation in this manuscript, and these prescriptions vary along with the need to maintain the social order of the community. Scholar Unto Tähtinen (1976) states that as far as Indian traditions go, even though ahimsa is definitely an important pillar when talking about spiritual purity, it has no intrinsic value 
on its own. Because ahimsa is the refraining from accumulating karma by killing or doing harm, the exertion of violence itself is not inherently valued. I would like to argue otherwise. I believe that both souls and the general concept of violence have fluctuating abstract values that, whether consciously or not, function to keep humankind at the center of focus. In Pierre Bourdieu's (1993) discourse on the production of beliefs, the symbolic value of art is analyzed in order to understand how humans valorize abstract products. If "art" were replaced by "virtue" and the art dealer is replaced by narratives, then the connection between intolerable actions and prescribed violence becomes more evident.

Because intent and the exercising of himsa are closely linked, the penalties (consequences) due to violence greatly fluctuate depending on how, why and against whom it is directed. Let's look at the following example. As far as Jain cosmology states, everything in the universe is divided into three major groups, the sentient (jiva), the non-sentient (ajiva) and that which is neither (arupi-ajiva) (Jaini 2014, 96). Among sentient beings, different creatures are attributed with varying numbers of senses, one to five. The number of senses a living thing has dictates the hierarchical level in which they are organized, given that only those with five senses are capable of spiritual reasoning. Although humans are not the only five sensed beings, they are the only ones capable to reaching liberation. This human exceptionalism is reflected in narrative as they portray living beings' importance in direct 
relation to their abstract value. Such value then serves to justify acts of violence depending on the circumstances. Jaini gives the example of a tree as being not a single entity but an enormous conglomeration of souls all limited to the sense of touch (Jaini 2014, 110). Because all of these souls however, are at a much lower spiritual level, the consequences of any harm directed to them may not be the same as harm directed to other beings. Animals possess all five senses which creates a controversial relation not only between them and humans but between them and the plant world as well because the karmic backlash and resulting rebirth received from harming an animal does differ than that of harming a lower tier creature such as a plant.

There is an obvious yet ambiguous relation between humanity and the abstract value attributed to not only the concept of non-violence but to the rest of the precepts as well (non-stealing, celibacy, truthfulness and nonaccumulation of possessions). Jain ideologues attribute worth to all that surrounds us by means of how ahimsa applies to it. To act virtuously then, would require understanding this worth and exercising violence accordingly. This process, as it often appears in narrative, has developed a solid abstract cruciality and become culturally influential. Now, from an everyday perspective, the spiritual value of the practical application of these concepts varies greatly, and this is often reflected in didactic literature.

Let's visit the sub-story of Dhanavaha to put the prior statement into a better perspective. This tale is part of the story of Vasunanda, which appears 
in the sixth canto of the LVS, "The Consequences of Greed and Acquisitiveness." This character is the son of a wealthy merchant. In order to test his father's advice on the benefits of staying away from bad company, he decides to serve a feudal lord and becomes friends with his servants. In a heated battle, Dhanavaha saves the lord's superior from an enemy king and his act was thanked and rewarded. He insisted on allowing his chief to keep the rewards, to which the chief was anything but pleased. So, in order to test the virtues of his master, the main character decided to steal a peacock that belonged to him. He divulges that he ate the animal out of hunger and the feudal lord, instead of helping him, arduously attempts to get him killed. After he realized that these people were mean and ill-minded, Dhanavaha decides to serve a different king who, pleased by the merchant's humbleness, gives him a special position in court. Here, the main character decided to test his new friends, the advisor Devadatta and the merchant Yashovardhana, and hid the king's infant child and nurse away in his chambers. Both of his friends from court covered for him and the king forgave the ordeal because he recognized the main character's good heart.

This story is filled with examples in which the significance of violence and the lines of morality become ambiguous at best. Beginning with the main character Dhanavaha, who is a merchant described as an honest man. His practices are not criticized and the goal of proving the worth of his friends is made clear. However, throughout the story this man lies, manipulates, and 
even kidnaps a child for the sake of proving the virtue of having good friends. This behavior is not necessarily justified but simply overlooked as the focus is on the response of the different friends being tested. Secondly, his friends lied when the situation required it. Although the act may be seen as noble because it was aimed to save the main character's life, it still actively carries violence. Thus, acting virtuously often blurs the implications of himsa and how that relates to the world around us. Violence is accepted and justified as long as it is prescribed. In the previous story, the importance of the proper/prescribed practice of himsa is highlighted and put in the spotlight: the story describes how the main character deceives, slanders and manipulates his supposed friends in order to test their virtue. And, because this is done through engaging with the experiences of the characters, the message or moral of the story becomes quite flexible. It is up to the reader to efficiently apply it to their respective needs (Fynes 2005, V.1, 421 ).

\section{II.IV Narrating Virtue: The Righteous Archetypes}

As we have seen in the previous examples from the LVS, the concept of goodness, of virtue and piety in narrative are not described in a list or in the form of precepts. They are rendered through the events and the decision making of the characters in the stories. There are however, prevalent techniques through which to accomplish this: The use of symbolic language, the personification of religious goals such as a paramount sense of morality and spiritual enlightenment along with the creation of layered meanings 
within a single story exemplify only but a few. The issue here becomes one of understanding how to address the peculiarities of each trope and how specific characteristics are transmitted through the different stories. Langer argues that language is to be defined as "through and through symbolic", meaning that speech can often convey specific meaning, yet it always bears an abstract structure which cannot be separated from the primal need for communication. "The transformation of experience into concepts, not the elaboration of signals and symptoms, is the motive of language" (Langer 1956, 113). In order to bring these texts to life while giving them proper justice, one needs to understand that there is an abstract relation between the reader and the context which resonates at a personal level. The use of language to create an aesthetically pleasing literary piece can often go beyond what is auditorily enjoyable and fall into an aesthetic depth that many times becomes impossible to translate. However, a script like the LVS, which was designed to illustrate socio-religious doctrine with a straightforward, very direct kind of language does not fully abide by these prior issues. Didactive narratives effectively perpetuate key values by creating allegorical archetypes and attributing them to particular, recurring characters which are able to keep their significance through translation. Such peculiarities are directly related to how virtue is rendered in each specific story. Let's use this section to analyze a few recurrent ones: The archetype of human males as representatives of the normative ideal of virtue 
and the tropes focusing on virtuous behavior instead of the attainment of liberation and virtue as an anti-fatalistic choice.

Even though, as mentioned before, all souls predestined to reach liberation will do so in time, narrative often displays how the nature of these souls' virtue is impacted by the body in which they are born. Appleton (2015) discusses one important motif in both didactic and canonical Jain literature, the emphasis put on female human and animal rebirths and the kind of karmic makeup that would get one there. Many times, immoral practices such as deception, whether it is self-inflicted or forced onto others, guarantee that a soul will suffer through a sequence of animal or female births before it can return to the human realm as a man (Appleton 2015, 22). It can be argued that a birth as an animal serves as a penance to the soul. Because of their inability to liberate in an animal state, their abstract value becomes lesser than that of humans and their worth can only be balanced as karma sheds through their many rebirths. The narratives, however, emphasize animal and female births not only as regrettable but as spiritually incomplete; thus their representation of intrinsic virtuous behavior becomes an exception. They become an example because they are not expected to be good, which, I argue, puts male humans' spiritual value at an advantage: Thus, virtue as represented by a human male becomes the standard most popularly portrayed in narrative, while women and other sentient beings become exceptions to that norm. Instead of choosing one 
specific example, I believe it is necessary to highlight the lack of significant roles being attributed to creatures other than human beings.

There are very few instances where the characters in these stories are reborn as animals, and even when they do, such lives do not play a significant part of a character's journey. The seventh canto of the LVSLVS, "The Consequences of Addiction to the Pleasure of the Sense of Touch," tells the story of a king who, after seeing the picture of a beautiful queen, shown to him by a heretic nun, decided to attack the kingdom where she lived and kidnap her. When this event did not go as planned, he was killed in battle and reborn as an elephant who fell in a pit and starved. The description of this animal birth is brief and serves only to show how unvirtuous actions steer the route of the soul after death. It could be argued that due to the nature of the text, a focus on human beings is necessary. Yet, given that the piece focuses on how to properly act in the presence of temptations there is an underlying layer of disregard towards other sentient beings, a lack of importance that tacitly denigrates their ability to do good.

This same pattern can be seen in the story of Arisimha, in the LVS's ninth canto, "The Consequences of Addiction to the Pleasures of the Sense of Smell." After spending some time in hell for fighting his own son, Arisimha is reborn as a snake that, only because it is exposed to a mantra at its dying breaths, is reincarnated in a human body once more. Here, we can see the focus 
on human agency, the need for virtuous human influence in the spiritual development of other sentient beings. Arisimha is given no spiritual authority as an animal; the accumulation of merit due to the mere sound of the mantra supports the idea of animals being able to progress spiritually, yet the act was not provoked by the animal itself.

Lastly, the longest focus on an animal is in the sub-story of a parrot and his past lives at the end of the fourteenth canto, "The Initiation of Surandhara and Kusumasekhara." This animal birth was the result of the recurring murderous thoughts of a king. Picked up by a group of ascetics however, the parrot was taught to repeat sastras (meaning manual or scripture) and, when reminded about his past births, the animal attained clarity and inquired about his spiritual future. As five-sensed beings, animals can become aware of their spiritual demises and make decisions to improve them. Although not often, some animals are even argued to possess qualities of spiritual growth. This text follows this theme, given that the example of the parrot exists as an exception. The problem in this manuscript is not that lives as animals are frowned upon, the problem is that they are barely mentioned and when they are, their influence in the spiritual growth of the soul in question is but neutral at best. Nevertheless, the link between religious meaning and non-human creatures is evident. As active links of the ecosystems that surround humankind, these creatures are part of the cultural platform through which the aesthetic of human environments are studied. What I mean here is that 
the roles non-human creatures have to play within narrative, alters the way we understand our position within the Jain spiritual hierarchy. The issue that emerges here, is that literary portrayal of all surrounding organic and inorganic matter begins to shape a long-term memory of both a physical and co-depending spiritual order that was never there to begin with (not as it was imagined anyways) (Berleant 1992, 50). This illustration becomes one more way through which anthropocentric ideas are solidified in the tradition.

Even though in canonical scriptures as well as in a great number of commentarial literature final liberation and bliss is the ultimate goal of a soul's very existence, the focus on virtuous behavior instead of the attainment of moksha is very common. With this I want to highlight the focus on articulating non`soteriological virtues as they are linked to spiritual advancement. There are many textual examples that state the amount of steps laypeople are not only allowed but encouraged to take to expedite their attainment of liberation. As stated in the srāvakācāras, a body of texts that denotes important rules and regulations for lay Jains, both laymen and women are prescribed penances and detailed descriptions of how to make up for broken vows or specific misdeeds. Narratives present this information differently, as they often focus on the inadequate acts that are to be avoided as well as on the consequences they may bring. Although forgiveness and redemption are often the overall theme, the focus of many didactic tales is that of understanding why incomplete paths to liberation should be avoided. 
In the LVS's second canto, "The Story of Prince Ramadeva and the Consequences of Anger," the relationship between Agnisarman and his stepfather illustrates how the previous theme is rendered in literature. Agnisarman is a young Brahmin man whose life is used as an example of bad virtue. Because of losing his parents at an early age, Agnisarman was adopted by a close family friend, who even gave him his own daughter in marriage (Jinaratnasūri 1983, 38-48). Now, Agnisarman was not only described as unlucky but unmotivated and temperamental. He hated his father-in-law and the rest of his family, yet throughout the story, his wrongful actions would be highlighted and followed by advice from Visnumitra, his maternal uncle, and even from the father-in-law himself, who was a virtuous man. In this story, the main character is again and again given the opportunity of redemption, along with explanations of how to turn his life around. The rejection of those good words of advice serves to demonstrate his spiritual immaturity which, as far as the text goes, directly hampers the human ability to act in a virtuous manner.

The focus on virtuous behavior in all of these tales presents a rather obscure or ambiguous layer of fatalism. This allows for the introduction of nonsoteriological virtues which are linked to spiritual growth but are, at the same time eschatologically contradictory. Different from the Ājīvika view, for example, Jains believed that destiny could be altered by devotional practices and one could expedite the path towards liberation through the right worship. 
This, however problematizes the role of virtuous behavior as the method of choice which becomes quite polemical in this text. In LVS's thirteenth canto, "The Rebirth of Ramadeva as Prince Vimalasena and his Enlightenment" is narrated. Because of a promise made in a previous life, a god had agreed to awaken this prince when the time was right. The deity attempted to recite a sacred mantra that would trigger Vimalasena's spiritual curiosity and, although it took many tries before the recitation achieved its intended effect, the prince ultimately heard it, reflected on his life and renounced all worldly things. This same event happens to prince Surandhara in the fourteenth canto and to Kulamrganka in the fifteenth. Even though the effective exertion of virtuous behavior is seen as a catalyst for spiritual growth, many times it is fate that carves the paths of the characters. These princes were all awakened by a third party, a being that understood their proximity to their goal and that had agreed to help them get there. What role does individual morality play here however? Virtuous behavior seems to be highlighted as a necessary aspect of social order; it is described as imperative and helpful when addressing final liberation yet, as far as these narratives go, it is not absolute nor required to reach Moksha.

In this text, although in many cases liberation is an obvious goal, the focus tends to rely in the process of following the right path. This is seen as expressions of virtue take the spotlight over the attainment of spiritual bliss. This technique is able not only to transmit religious messages pleasingly but 
imposes rules for social order, gives filial and political advice, and perpetuates spiritual hierarchies in which humankind is put at the center of spiritual progress. As we experience these characters progressing through chains of rebirths, their spiritual maturity is directly related to their intrinsic motivation to do good or act virtuously. The idea of intrinsic good seems to be the first step towards religious transparency since it is imperative for the characters to be aware of the right path themselves before they can have the subconscious urge to help others. This would require themselves to work towards the shedding of their own delusion before being able to process selfsacrifice. The consequences of these expressions of moral behaviors fluctuate in relation to a character's intention. The penalties for violent behavior are directly linked to the perpetrator, the victim and the ends of any given act. This then, places the classification of sentient beings into the hierarchy of senses that ought to be considered when exerting violence.

\section{Conclusion}

Having gone over these examples, it is imperative to consider the many layered nature of virtue and what this means in didactive narrative. Moral acting, as far as it is portrayed in these stories, cannot simply be described as means to an end. To act virtuously in the tales is not simply to follow the rules and respect both the spiritual and social norms. There is also an innate desire to do good for others, awakened by a character's spiritual maturity that needs to 
be accounted for. So virtuous behavior is to be attributed to the intrinsic human desire to be moral or to follow the rules that will ultimately lead them to liberation, yet virtue and the innate desire to do good for the sake of others needs to be addressed as a different phenomenon. Given that many times, characters will consciously act in questionable but justified ways if the end result is considered spiritually beneficial, the need of analyzing self-sacrifice as a reflection of extrinsic good becomes evident. Because the LVS often portrays discrepancies between these two concepts, I propose that, instead of finding a middle point between these views, the more effective way is to combine them into a new, more efficient way to analyze the role of morality as it is rendered to the masses through didactive narrative. To effectively do this, however, we must first account for the role that karma and destiny play in virtuous decision making as well as look at how the narratives of neighboring traditions are affected by these same operations. 


\section{Chapter III}

\section{Sources of Virtue in Narrative: Karma, Destiny and Intent}

\section{III.I Virtue and its Catalyzers: Understanding Goodness as attributed to}

\section{Karma and Fate.}

The topic of virtue becomes quite complicated when the goal is to define the root of such behavior. This is significant because much didactive literature revolves around morality and proper decision making. As Kelting (2009) points out: in these narratives, liberation or the final goal to be reached by a character are frequently not delved into. Ordination and enlightenment are not necessarily taken for granted per se; in fact, they are often the main focus of every other passage yet, the earthly events that characters experience in order to arrive to such goal tend to be the ones that expand and receive the spotlight (Kelting 2009, 74). The catalysts of such events, as they are portrayed in texts are often karma and fate.

Karma, fate and virtuousness are very closely linked, since morality, seen as an intrinsic desire that grows and develops along with one's spiritual level, becomes directly dependent on an individual's karmic print. What happens in didactive narrative is that the introduction and disentanglement of all these influencers build layers of meaning through a design which can appear very linear and simple at first sight. This phenomenon is reflected not only in Jain narrative but in Hindu and Buddhist work as well (Bronkhorst $2007,144)$. The influence of both karma and destiny as well as that of human 
agency are utilized not only to inform the listener about their own role in the path towards liberation but are often employed as tools that justify the superiority of a specific religious community. This creates a link between the concepts of ahimsa and innate virtue. As Bourdieu (1993) states in The Field of Cultural Production, "the meaning and value of words (...) depends on the market to which they are uttered; (...) the same sentences can take on opposite meanings when addressed to groups with opposite presuppositions" (Bourdieu 1993, 276-7). And so I argue that, the role of karma and its complicated relationship to virtue and fate in didactive narrative, in our case the LVS, is used as a tool to justify moral behavior and to create value for the tradition in question.

To successfully accomplish this, the use of language, tropes and archetypes is crucial. In order to create an emotional reaction from a literary piece, and to incite demonstrative responses from the reader, a number of mechanisms can be effectively utilized. Sheldon Pollock discusses the concept or linguistic modality of what he calls "implicature" or "manifestation" (Pollock $2018,19)$. This, he explains, refers to the process of experiencing the emotions being transmitted in a way that a linguistic phenomenon becomes a cognitive phenomenon. So, the point of a narrative is not to just inform the listener of the influence that karma might have had on a character's life but to immerse them in the experience at a level where they can relate to the event and give the issue in question an abstract value to be spent at a social level. The first 
question we need to ask ourselves is what qualifies as tasteful or skillful writing as far as it is understood in the west, and in what context do we place it when talking about medieval didactive narratives? One of the biggest parallels between India and the west is that of the problem of emotion in literature. The process of embedding a text with sentiment as to captivate and engage the reader becomes not only an apparent intention but an anticipated goal (Pollock 2018, 4).

The LVS certainly includes these previous methods, connecting the reader with the different characters at an emotional level and providing examples that are relatable even in the contemporary era. The manuscript often focuses on the many hardships that bad decisions bring to human beings. It carefully selects events and highlights how human agency and innate virtue function as separate entities that are to be decided by one's own past lives' mistakes. Now, as Steiner discusses in his work After Babel(1998), it is crucial to understand that besides having competency over the languages in question, either in India or the West, there is an abstract comprehension of what conveys meaning. We must consider the fact that all humans are capable of experiencing the same emotions, whether positive or negative, even though they use different words to describe it. Accessing the range of emotions a text is trying to convey is key to a better understanding of narrative literature, no matter its origin (Steiner 1975, 67). A brief example of this lays in Folkert's discussion of the fluid yet rather ambiguous introduction of ascetic values into 
a layperson's life. Because for the Jain community, laity is simply seen as a preface to asceticism and as part of the continuous evolution of a soul whose ultimate goal is liberation, having narratives with moksha as a goal is rather popular, even if that goal is overshadowed by a focus on terrestrial issues and/or events. The focus on topics like proper behavior, the consequences of immoral acts, marriage, lust, deceit etc. can make a sole narrative quite intricate because numerous socio-religious ideas can be effectively transferred over a single storyline. Because of this, uncertainty or ambiguities are bound to emerge. Folkert states that it is important to analyze how the portrayal of all these different topics or tropes are portrayed in literature. He states that the outstanding amounts of effort put into attempting to regularize renunciation for example, just as Hindu law books do, as well as the role that the community (being such a small minority) plays into the lives of the ascetics is crucial to understanding their socio-religious changes throughout the years(Folkert 1993, 183). Thus, portraying these ideas though stories in which an emotional connection can be made with the characters becomes key to generalizing and creating socio-religious value within a community.

The LVS will often effectively employ this technique to allow the reader to empathize with the characters and their ventures. Thorough use of speculation and placing the characters in a state of unawareness, allows the reader to experience the events from afar while also participating in the process. Because this poem presents events as they are experienced by such 
characters, attempts to separate the use of karmic residue from that of fate and human agency in respect to innate virtue can become challenging. I believe we must refrain from relying too much on our western understanding of style and what is to be expected of a certain text. Instead, these stories must be able to read them as an architect would read the first blueprint for a remodeled structure. I believe that by understanding these sagas as not only a religious code but as a master blueprint for social interaction that can be remodeled and adapted from one tradition to another can help us realize the significance of language and style in order to enhance the effectivity of meanings conveyed. And so, even though the depth embedded in translations needs to remain true to what is being narrated, I believe that the significance of these stories goes beyond the linear timeline that could be lost in paraphrasing. As Steiner states,

Language is a constant creation of alternative worlds (...) In one sense, each act of translation is an endeavor to abolish multiplicity and to bring different world-pictures back into perfect congruence. In another sense, it is an attempt to reinvent the shape of meaning, to find and justify an alternate statement (Steiner 1975, 246).

Karma carries an ambiguity that is shared across India's most popular traditions. Bronkhorst quotes the Brahmanical text, the Devibhagavata Purana (6.10.34) as it states that "the course of karma in a living creature tied to a body's deep and mysterious, hard even for the gods to comprehend; so how could men understand it?" He mentions the Buddhist Abhidharmakosha of 
Vasubandhu and its discourse on how "Karmic retribution of living beings is incomprehensible". Lastly, Bronkhorst also quotes the Mahabharata's description of the retribution of living beings as incomprehensible and then continues by quoting that "the fruition of acts, both good and bad, their origin and disappearance, are the mysteries of the gods" (3.32.33). However, the concept of Karma as a force that influences the amount of innate virtue a soul will have, is very visible in text. Although, surprisingly enough, the way in which the fruition of karma is rendered through literature does not focus on the metaphysicality and design of such substance but in what it can do to souls. As mentioned in the previous chapter, with an underlined spiritual hierarchy existent in Jain cosmology, anthropocentric hues are clearly seen in didactive texts, however, the concept of karma and how it operates is still understood within a reassessed, and leveled humanity.

Because Karma in Jainism works as a physical substance that adheres to a soul at a molecular level, the theory behind it, different from the abstract value utilized to place humanity at a spiritual center, focuses on an even scale. Hewlett's perspective fits this view well as he states that "we are moving from thinking of humans as simply the sum of their genes to understanding living systems as vast and complex networks of interactions out of which emerge properties of the organism" (Hewlett 2010,156). What this means is that, in order to understand how karma operates within narrative then we must separate its functionality from the anthropocentric nature or virtuousness. In 
fact, to do this, we can no longer think of humanity as a single unit, independent and alien to all other aspects of existence. We cannot elevate the human existence above the microscopic networks that serve as the base for all organic functionality. Thus, for the sake of understanding the operational side of karma, I propose rethinking our definition of humanity in this chapter as communal and dependent. Because we, as humans who are at the mercy of the world around us (environmentally speaking), reflect such fears and doubts through the writing of our history, whether in the form of myth or cautionary tales (Hewlett 2010, 155).

Scholar Wesley Wildman argues that due to this realization that humans are but an ecosystem of their own "the harmonizing mechanisms that produce the miraculous equilibrium that is human life are therefore both biological and cultural in character. The symbiotic relationship between humans and innumerable communities of microorganisms is very nicely explained within the Jain cosmology so, why should we assume that the manipulation of karmic residue is limited to humans alone? How can karmic shedding be attributed solely to humans when unicellular life is intrinsically bound to the human body and absolutely necessary for humans to exist? Keeping these organic ecosystems at a balance are not to be only analyzed as spiritually beneficial, our life literally depends on it. Thus, the role that karma plays regarding our interactions with these microbial communities becomes much more complicated (Wildman 2010, 172-3, 177). On top of that, karma 
often works as the force that steers the fate of people while also separately dictating their level of innate virtue. What becomes interesting is that after these ideas solidify, the sense of a specific community's dharma as the right one becomes apparent. So, the operational side of karma which is explored in narrative as well as its relation to following the correct religious path and the presence of innate virtuousness all work as tools that solidify the socioreligious agenda of the community.

\section{III.II Karma and Fate: An Ambiguous Correspondence.}

A common theme in Indian didactive literature is that of narrating the life of a soul through countless lives, sometimes the sagas branch out to include other souls which happen to follow a similar path and find their way back to the main character. Although in Jainism our karmic print is like a fingerprint, unique to the individual in both shape and size, the existence of karmic bonds is very clear. Interpersonal karmic bonds are often reflected in literature; souls keep meeting again and again through multiple lifetimes in order to pay their karmic debts to one another. These karmic debts are many times payed in the form of teaching: Many characters in the LVS, weather because of a promise or by chance, use spiritual maturity as a tool to steer other people into the right direction as rendered in didactic stories would have to be classified as a kind of inter-personal karmic bond because as canonical text will argue, one cannot simply comprehend knowledge without having experienced self-clarity and a 
significant loss of karmic residue first, yet listening to a monk talk about the right path to salvation is often reason enough for heretics to reconsider their ways (Appleton 2015, 135). Appleton quotes Walters, who states that we cannot ignore the communal aspect of karmic consequences and the quite important role they play in the social dimension. He mentions that many religious activities, as well as many demeritorious events, are often not an individual practice and that, separating a group of individuals to judge the significance of their actions is simply inadequate. He states that:

Karma as a result (vipāka, phala), inevitably has social dimensions because the goodness or badness of a good or bad rebirth is largely conceived according to social categories such as family, status wealth, caste, power, and/or political situations. Even birth among the gods, animals, or hell-beings has its social dimension (Walters-Appleton 2015,127).

Walters proposes two different theories through which to analyze karma's social dimension: merit transfer and, inter-personal karmic bondage. Explicit merit transfer is not common, in narrative, not as an active practice at least. Instead, the characters experience events where assistance can be given by those who are karmically connected to them either in a positive or negative manner. Thus, inter-personal bondage becomes more clearly seen and expressed in literature. Let's revisit the main storyline of the LVS: The saga revolves around a group of friends, who, having met at a religious debate, were enticed to attain spiritual liberation, helping each other throughout their rebirths until they are revealed to have been born one last time as king Simha 
along with his counselors and wife Līlāvatì. All of this justifies the idea of the existence of this communal consciousness where a person is "correlated with all of his other forces" (Walters-Appleton 2015,127).

It is here that the intrinsic value given to violence takes the spotlight as opposite to the virtue brought up by the shedding of karma. Violence, as represented through narrative, is placed within this broad yet still very limited spectrum of themes that can then be countered with the appropriate application of virtuousness. Palmer states that "the knowledge that I am an I cannot be conveyed to me by another human being., nor can I perceive anything similar in him. Each must ascertain it for himself." Yet the idea that enlightening or earthy experiences cannot be lived for others, or that selfconsciousness and true knowledge are both to be personally experienced, as far as narrative goes, can both be triggered by a second party through the exertion of the appropriate practices (Palmer 2010, 78-89).

The LVS, beside making very clear connections between karmic residue and the amount of innate virtue a soul is to be born with, also justifies the superiority of the dharma as it correlates birth in the Jain community as a sign of good merit and fortune. Let's look at the life of Līlāvatī's husband, king Simha. At the beginning of the story, the birth and early childhood of this character is explained. He was born to King Jayadharma and queen Padmavati, who devoted their faith to the Jinas in order to be blessed with a 
son. Their conception was aided by a Yaksha, a divine protector of the Jain Order, who responded to the proper worship. The soul that took refuge in the queen's womb traveled from the heavenly realms; she was made aware of her pregnancy by a dream of a lion which entered her mouth. Through the following months, she then started having an inexplicable urge to worship the Jinas, avoided eating meat and stopped the slaughter of animals. She also started paying respect and giving alms to ascetics. Her husband did not only agree but encouraged these practices and, thus, a healthy male boy was born. Simha is described as an obedient and smart child. When he becomes old enough he marries Līlāvatī, who gave birth to a son. One day, all of a sudden, King Simha hears some auspicious verses that could not be traced to anything or anyone, so he assumed it was an omen of spiritual maturity and called for a royal debate among monks and scholars. It is only revealed at the end of the story that the verses were recited by his friend from a past life who had a karmic debt to repay (Fynes 2005, V.1, 35-87).

There are a couple of events here that are worthy of debate, the blessing of Simha's birth being the first. Because it is revealed that the soul of this character was destined to liberate in that birth, the link between auspiciousness and intrinsic virtuousness and a Jain birth become evident. Not only was Simha born to devout Jain parents, he was raised and schooled within a dharma that most efficiently paves a path towards liberation. It becomes clear in the example that there is a positive correlation between his birth and 
his proximity towards liberation. However, it had already been established that his friend from a prior existence would help him find his way to moksha, so it becomes extremely hard to define where the weight of karmic residue starts and where the rigidity of fate takes over. The other problem that arises is that of virtue as not being inherently part of a soul. We could say that karma is a cloud of blinding dust that impedes the soul to understand it's full benevolent potential. This supreme, omniscient nature would only show when the residue has decreased due to tapas or auspicious behavior but then, if this was unique, human agency would have to be discarded. If someone is able to awaken by the words or mantras of another just because he/she was destined to do so, then this would mean that the relation between karma and virtue are neither crucial nor exclusive.

So, chance or inevitability do have a place in narrative and are connected, but not dependent to the rules of karma. An important question that could help clarify the role of destiny as it associates to karmic retribution is: Can fate be fooled and changed, and if it does, how can it be so? Even though Jain texts describe karma as a cloud of physical particles that keep the soul in a blind and ignorant state, the way that karma? is rendered through storytelling is quite similar to how it is described in bodies of literatures in other religious communities. The laws of cause and effect are not only clearly stated but the inevitability of one's karmically dictated destiny are carefully highlighted. To clarify this point, let's look at the sub-story of Buddhisagara 
and the astrologer's prediction. The minister Budhisāgara was warned by an astrologer, in front of the king at the royal court, that a fatal event would bring doom to his family within a two-week period. The astrologer told him later in private that such awful event would be brought about by his son Subuddhi. After stating "One is to renounce for the sake of the family. Having been reminded of that moral conduct of yours, let that be onto me indeed. Let auspiciousness everywhere around the family ${ }^{9 "}$, Subuddhi cooperated with his father and allowed him to seal him away in a wooden box with enough space and provisions to last a bit over the required time. The minister asked the king to assign his best men to guard the box since his own life depended on it. One night, the palace awakens to the complaints of the king's daughter. She stated that Subuddhi had cut her braid while she slept, which made the king furious. At this point Budhisāgara takes the royal family to open the box where they find the young man with a blade in one hand and hair in the other. After confirming with the guards that such box had never been opened, the minister and his family were spared and generously rewarded (Jinaratna 2005, Volume $1,161-167)$.

This short sub-story solidifies the idea of fate as being merciless and inflexible because it illustrates how, although one can get away with changing fate-related misfortunes, some events will inevitably come to fruition. The

\footnotetext{
${ }^{9}$ Please refer to verses 43 to 47 in Chapter 1, The story of Buddhisagara
} 
minister was wise enough to find a method through which he could prove that the bad actions of his son were divinely mandated, yet he was not able to stop him from doing them. If taken at face value, Subuddhi had no way of escaping his imprisonment, yet the prediction still became true. What did change, due to the father's wit, were the consequences brought forth by such events. Although the minister and his family were destined to suffer through calamity, they managed to acquire wealth and respect from the royal family. Thus, what this story is trying to convey is that an individual's destiny cannot be avoided. Once karmic residue becomes physically rendered in a present life, events will unfold as fate dictates; however, through human agency and right action, the consequences brought about by these unavoidable events could indeed be shaped to one's own benefit.

The same intricate karmic connections can be seen through the experiences of Vasundhara's soul. Once this fake monk is ridiculed and impaled by the town's people, he burns much of his bad karma in hell and is then reborn as a beautiful girl called Yashomatī. This gifted girl grew happily with her mother Radha and father Yajnadatta, who were both devout Brahmins. As she grew older alongside her brothers, the girl was married to a young and honest man called Somadeva, who unfortunately passed away in the night of the wedding. Because she kept her chastity, her family supported and honored her decision to become a nun. However, proud of her virtue, her youthful curiosity steered her towards lustful behaviors and inappropriate 
treatment of her own body. Her pride became so imminent as to even accuse a group of wandering nuns of being untrue to their vows. She explained to her incredulous friends that these nuns were happy to live alone in the forest because it allowed for them to be promiscuous and get rid of unwanted pregnancies without consequences. One day she decided to bathe in a pond. Because a man had washed himself after having intercourse in that same spot, swallowing some of the water caused her to be pregnant. Once her condition showed, she and her family were harshly judged by the town. Because she was rejected by her loved ones and ridiculed by the villagers, Yashomatī ran away and attempted to take her own life. Having been saved by a group of nuns and introduced to the Jain faith, she died during childbirth and was then reborn as a male prince (Jinaratna 2005, Volume 1, 179-189).

There are some important messages in this story that deserve to be highlighted. Starting with the correlation of bad karma and female births: because the soul of Vasundhara had accumulated so much karmic weight, it not only suffered through hell but had to come back as a woman. The connection is not subtle, it is transmitted in a way that not only informs about the phenomenon but also normalizes it. Now in this specific example then, we could infer that karmic consequences are destined to flourish under specific circumstances no matter what. The same could be said about the relation between her caste and religious background and the spiritual level of her soul. Different from King Simha who, being spiritually very close to Moksha, was 
born into a devout Jain family, Yashomatī, who still carried much karmic waste, was born into a Brahmin family instead. This is neither portrayed negatively or directly seen as a hinderance, yet the connection is made quite clear. As the story untangles, we can also see how her chastity is directly linked to her level of virtue and that of her family, she is not honored for her practice of austerities or her knowledge of sacred scriptures, her power is attributed to the preservation of her purity. Thus, chastity is also directly correlated to karmic influence, making it difficult to infer from the narrative alone, if the introduction of human agency could fool a fate written by bad karma. The most important point one must have in mind here is that of Yashomatî's pregnancy. Here the distinction between coincidence, fate and inevitability is a blur at best. Even though this girl was proud, liked to slander and lie about others and even involved herself in prohibited sexual practices ${ }^{10}$, she was not involved with another party at any point in the story. She did not even touch a man yet suffered from the residues of someone else's bad behavior. I believe we could interpret this event in two different ways: In the first, we could take this story at face value, accept that, due to swallowing the contaminated water, a pregnancy was caused, justifying that ill luck will fall on those who act unvirtuously. Even tough, I believe, the combinations of these events make it

\footnotetext{
${ }^{10}$ Jinaratnasuri's Līlāvatīsāra makes reference to Yashomati's lustful endeavors with herself in verse 131 of the canto: "Furthermore, she who in the burden of her puberty carried ideas of trembling desire, oh! She indeed became acquainted with a cycle of bad behavior (involving) herself and her own body."(See Chapter I for the complete excerpt)
} 
particularly difficult for the reader to identify and filter the influence of karma and destiny as separate entities, it does transmit the consequences of both in a rather effective manner. On the other hand, if we are to dissect the way in which these events are narrated, I believe we need to include the very clear possibility of Yashomatī as being sexually active and thus directly guilty of her own fate. The problem is that, holding human agency accountable here, would steer the focus towards a more mundane message and minimize the significance of the innate purity that is to be held by the different archetypes.

No discourse between karma and destiny as influencers of virtue could be complete without delving into the role of intent and human agency. One of the reasons why the concept of morality or virtuous behavior becomes polemical is the role of intent. As Tahtinen discusses, the practice of violence, is only soul-damaging if done with intent. He highlights the PurushārthaSiddhyupāya 3.43 by stating that “. Even when there is injury to life, it cannot be considered himsa if the person is not motivated by any kind of passion and carefully follows the code of right conduct." He continues by explaining that contrary to that statement, acting out of ignorance is always bound to violent behavior whether actual killing was involved or not. It is here that attempting to link a practitioner's resolve to the general concept of virtue becomes problematic because the depth and clarity with which virtue is explained between canonical texts can at times be contradictory (Taihtinen 1976, 6). It is difficult to place where in the spectrum of spiritual advancement intent is 
ought to be placed yet, didactive narrative manages to this in a rather pleasing manner. What I find fascinating is that, although in a rather passive way, the LVS portrays the role of intent as important but not crucial. What this means is that the saga manages to steer the influence of intention as crucial only when it relates to the practice of the right Dharma, in this case the Jain Dharma. Let's break these statements apart by comparing the following examples.

Devadinna was as an unlucky merchant who was not born with a gift for business. Because he could not find sustenance any other way, he started to pose as a devout Jan monk. Now even though he was sentenced to death after robbing the household that offered him refuge, Devadinna played the role of a monk quite well: he knew the right prayers and recitations, he appropriately performed the required rites and offered words of advice to lay practitioners, yet the narrative does not give him credit for any of these practices (Bhayani 1983, 79). Although different than from the Ājīvikas and some branches of Buddhism, Jains did believe that karmas (both good and bad) could be eliminated through the right practices. These performances (tapas) required strenuous and many times self-harming activities to be performed as a kind of penance (Tähtinen 1976, 24). Devadinna went through the motions but did not internalize the practices.

Satyamatī, on the other hand, born in the Magadha area and married at an early age, was fascinated by the magical display of a wandering nun. She abandoned her husband, murdered her first son as a sacrificial offering, 
mastered tantric practices and became a cannibal. However, because she happened to listen to some pious nuns reciting a mantra and, for a moment, reflected on their virtuous life, she did not only avoid the rendering of her bad karma through the layers of hell but was also reborn as a male son of a pious family (Bhayani 1983, 272)

So, what can we infer from the consequences of these characters' actions? Why are austerities and the correct practice of rites emphasized when they serve no purpose to those without the correct intent? Through these stories, the need to emphasize the right mindset as most important becomes apparent. Not only that, the link between intention as "applied human agency" and the consequences of karmic retribution are cleverly highlighted as well. The text recognizes the accuracy of Devadinna's practices, but because he decided not to abide by what they meant, the physical performance of them served him no purpose. For Satyamatī, the consequences were altered just because she voluntarily, through a moment of clarity, reflected on the virtuousness of another. An important issue remains here however, and it is the one of karmic consequences as related to the portrayal of inherent virtuousness. The bad actions committed by the characters greatly differ when it comes to their severity. Here we would need to go back to the application of value to the amount of harm they convey. Although the sins committed by Satyamatī caused much more harm than those committed by the fake monk Devadinna, her extremely brief yet intrinsic moment of spiritual clarity proved 
more valuable than a life worth of austerities done without the desire for spiritual advancement.

\section{III.III Accepting Fate, Karma and Inevitability as Independent, Interconnected Phenomena.}

Just like the story of Satyamatī, there are many other cases which solidify a direct relation between spiritual advancement and chance. The most important point of these passages is to highlight and clarify how the casual reflection upon the right teachings, in this case, the Jain dharma, is always more effective than the devout practices of the wrong faith.

As this point, the relation between chance, fate and karmic residue becomes apparent. However, their manifestation in narrative often becomes ambiguous and rather difficult to separate from one another. This can be enhanced by the experiences of Arisimha and Dhanadeva in the $9^{\text {th }}$ and $10^{\text {th }}$ Cantos of the LVS. The former, as mentioned in the previous chapter, after being killed at the hands of his son was born as a snake. Because a Rsi that happened to be around recited the Namaskara mantra to him, he was reborn as a male merchant wanting to reach the abode of eternal bliss. The latter after being sentenced to death over attempting to secretly meet with his king's wife, overheard by chance the recitation of the same mantra and recited it with faith while being impaled and was able to be reborn also as a male son to a merchant family with an innate desire to be initiated into the Jain order. Although these 
two examples reinforce intent as being crucial towards the effective shedding of karma, they also reinforce a very common trope: The interaction of souls with auspicious recitations that entice them to take monastic vows which is popular though this saga. Now, the main focus of this phenomena is to solidify the existence and efficacy of the right faith and how it operates in relation to a soul's karmic disentanglement. It serves not only to highlight the need for human agency to be focused on the right areas but also effectively justifies the superiority of a tradition over the others, meaning that the mere act of listening to such mantras, even if one does not understand them while reflecting on their sacredness can be more effective than properly practicing austerities and recitations.

\section{Conclusion}

And so, as far as it is illustrated in the Līlāvatīsāra, karma is related to both, virtue as a representation of extrinsic good, and innate/intrinsic good itself. This relationship however is neither crucial nor exclusive yet becomes quite intricate once we take fate and human agency into account. Karma, fate and virtuosity are very closely linked, since morality, seen as an intrinsic desire that grows and develops along with one's spiritual level, becomes directly dependent on an individual's karmic print. Surprisingly enough, the way in which the fruition of karma is illustrated in this text does not focus on the metaphysicality and design of such substance but in what it can do to souls. I 
believe that the LVS, beside making very clear connections between karmic residue and the amount of innate virtue a soul is to be born with, in a very direct yet stylized way, justifies the superiority of a particular dharma as it correlates the birth among the Jain community as a symbol of good merit and fortune. Having this in mind then and considering the fluidity that Virtue is attributed with in this text then it becomes a bit easier to analyze the role that different beings play as generalizations of their group. 


\section{CHAPTER IV}

\section{Women in Narrative: The Limitations of Female Agency and the Place of Women as the "Other" in Jain Didactic Narrative}

\section{IV.I The Absence of Queen Līlāvatī: The Role of Indian Women in the Early Medieval Period}

The first issue to be explored in this chapter is that of the subtle yet clear limitations women encounter in the selected stories. I do not intend to argue in any way that, through these sources, women were denied their ability to liberate or are portrayed in an absolutely negative light. On the contrary, the number of good and bad examples in which women take the leading role are rather balanced in the LVS. This does not mean however, that their position is not restricted and utilized as to complement the superiority of men. Let's first address the lack of involvement they have within the tales, starting with Queen Līlāvatī herself. As stated in previous chapters, the general storyline of this manuscript is that of a group of friends, who, finding themselves karmically connected, reach liberation through the teachings of a wise man. Lìlāvatî is one of those friends, she is present when her husband calls upon the sage Samarasena, she is present as the discussions on the consequences of anger, forbidden pleasures and the abuse of the senses were given and as the different characters of the sub-stories were enlightened by them. However, she was not actively involved throughout the story. She did not ask questions, she 
did not show curiosity in a dynamic manner, nor did she argue against any statement or story presented by the wise man. In fact, she only acquired absolute knowledge after circumambulating and praising her already liberated husband. The whole saga is truly focused on her male counterpart, King Simha. He was the one who showed spiritual curiosity, he invited sages for religious debates and, he asked the crucial questions, placing the Queen in a secondary position, and giving her a passive and aesthetically pleasing yet monotonous and colorless role. Dr. Altekar's book The Position of Women in Hindu Civilizations, starts with the phrase "The rules about sex morality enable us to know the ethical tone of the society and ascertain how far men were prepared to be themselves judged by the standard they had set for women."(CITE) He thoroughly discusses the role of women through Indian history and emphasizes the perpetuation of certain roles from very early on. What is interesting is that ancient India was much less discriminative towards girls who, were encouraged to initiate Vedic studies and were allowed to offer sacrifices. As ancestor worship became more popular however, the preference over boys became more apparent. This added to an increasing number of child marriages and the prohibition of the remarriage of widows around the $300 \mathrm{~s}$ BCE started to solidify a limited view of roles women were allowed to play in society. The shift accompanied by the lowering of marriage age in ancient India took a tremendous toll in women's education. What I believe is important to have in mind is that for women, different than for men, marriage was not 
recommended but obligatory. Whether it was because it was considered much riskier for unmarried women to survive within their society or because a "female deliberately vicious" life was much more frowned upon than a man's, the limitations imposed on girls started solidifying from very early on. Altekar continues by saying that:

When child and illiterate brides became the order of the day, the tone of the treatment which was given to them by their elders in their new homes began to change. Their legal status also had changed by this time. They had ceased to be queen in their new households; they were now regarded as pupils of their husbands, who themselves were still in the student stage (Altekar 1956, 92).

In the LVS however, the role of women is not scarce or insignificant. Yet, female characters develop across the intertwined stories within an extremely constrained set of acceptable rules deemed socially proper during the historical period. Beyond Queen Līlāvatī herself, many other women participate in the stories, yet their often intrinsically corrupted nature and their decisionmaking capabilities deem their roles limited and marginalizes them to the extent of a passive indifference. On the other hand however, as discussed above, although it is generally understood that there are clear issues revolving around strimoksha (the liberation of women), Sethi (2016) discusses how Jainism still offers one of the most reachable and wholesome possibilities for women to reach enlightenment. 
While the Digambar unapproving attitude towards the acceptance of liberating women is not only evident but ardently discussed, the truth of the matter is that, even in such case, liberation is not an absolute impossibility because a woman can always accumulate enough good karma to be born as a man later on and reach the final goal. Even if not ideal, Jainism facilitates the shedding of institutional constrains (such as that of marriage) that are intrinsically bound to women "by virtue of their femaleness" (Sethi 2016, 129). In many texts dating to earlier centuries $\left(6^{\text {th }}-5^{\text {th }}\right.$ centuries $\mathrm{CE}$ ), female renunciates and laywomen are placed at the same level as their male counterparts (Sethi 2016, 3). Texts like the Chaturvidhasangha ${ }^{11}$ for example which explores the roles of Sadhus, Sadhvis, Shravakas, and Shravikas is more concern with laying out rules of conduct and how to effectively abide by them while popular narrative functions to apply this theory. The issue that surfaces here then, is that the secondary, often ambiguous role of women in texts like the Lìlāvatīsāra is illustrated and cemented under a very particular light.

Although very subtle, the tendency in the LVS is for souls to liberate once they are reborn in a male body: The male main characters find liberation by being exposed to their past lives and enlightened by a wise sage, while the female characters only achieve Mokșa after worshiping the spiritual maturity of their husbands (Jinaratnasūri's 2005, Vol.2, 611-14). What is important

${ }^{11}$ This refers to the four-fold Jain order which consists of Sadhus, Sadhvis, Shravakas, and Shravikas. 
from this is that, even though all the main characters find liberation at the end, men are the primary focus of the event and females are portrayed as spiritually dependent on the initiative of men. Flügel dissects the concept of atonement in the Tilakacarya's Savayapacchitta, a Svetambara Jain scripture that deals with penances required by monks who break their ascetic vows. He discusses how atonement for the violation of certain oaths (in this case those related to sensual pleasures) were given to both men and women using the individual to assess the situation, not their gender. He also emphasizes a set of verses particularly made for laywomen which, he believes, serve to reinforce the Śvetāmbara acceptance of female spiritual potential and with that, their own socio-religious identity. These verses include the recitation of namaskara mantra to women who rubbed against men during religious practices (Flügel 2018, 93). The point I want to highlight regarding Flügel's research is that even though there was a distinctive divide between the rules for atonements between monks and laypeople, devaluating differences between these practices regarding men and women was not a direct goal. This is not so clearly portrayed through the LVS.

Literature was not the only method employed in transmitting social dogma to the masses. In Dr. Joshi's study of donation inscriptions in Gujarat, she debates the overwhelming patriarchal values reflected in women's inscriptions. It is clear in her research that women had a certain autonomy within the accepted norms, yet there is a prominent pattern of male dominance 
that carries throughout the late medieval period (1000 to $1400 \mathrm{CE}$ ). She also closely analyzes the role of women among the Śvetāmbara Jain canonical texts (mainly written from the $3^{\text {rd }}$ century BCE to the $6^{\text {th }}$ century $\mathrm{CE}$ ). There we find plenty of praise dedicated to women: The mothers of important characters, virtuous wives and chaste females are generally venerated, yet these figures are valuable only with respect to what they mean to men. This sense of virtue, as far as Dr. Joshi is concerned, can many times be attributed to the acceptance of a patriarchal society by women in return for protection. This attitude towards life created the underlying idea of obedience and humility as a crucial component of woman's virtuousness (Joshi 2009, 136). The conflict also feeds the existing issue of sexuality and asceticism, where men are seen as having an impulse towards chastity while females tend to represent sexual desires (Sethi 2016, 66).

Kelting (2009) discusses the effects of Strategic Piety from a social perspective stating that this phenomenon "can span acts as disparate as a woman taking ordination to effect a permanent break from her husband's family to a woman's increased religious practice to create a more pious self" (Kelting 2009, 73). There is more to holding responsibility for the reputation of your household and husband, than what the practice conveys at first glance. Women are attributed very specific roles in a household; these roles are important yet prescribed in a manner that keeps their hierarchical position rather stifled. A common trope in literature for example is that of women who, 
besides choosing their religious practice over obligations to their spouse, utilize their religious piety in order to improve both her and her family's reputation and status.

If a family has a good moral reputation, then the assumption is that the women in the family are moral and, if a woman in the family acts immorally, then the morality of the whole family is called into question (Kelting 2009, 75).

Although this practice can be rather empowering from the wife's viewpoint, as far as Dr. Kelting agrees with Mahmood's article, I argue that this whole process is nonetheless very restraining. I do not intend to deny that the whole operation can indeed be positive from their particular perspective, yet it is objectifying at its core. It marries women to the specific set of roles they are allowed and encouraged to play within society. A role that facilitates oppression because of the imbalanced penalization system: It is much easier to devaluate the morality of a family versus having to build and uphold virtue and piety. I believe the story of Madanamañjusa and her sister Madanashalaka can help us untangle the statement above.

This story is part of LVS's $11^{\text {th }}$ Canto: Consequences of Addiction to the Senses of Hearing. It states how the sisters were raised under proper guidance, being taught about the arts and scriptures. They were respectful towards their parents and paid ascetics and wisemen the proper homages. During a pilgrimage, Madanamañjușā met prince Mahāshanijava, they fell in love with 
each other, so her hand was properly asked in marriage to her father. Her sister decided not to choose any of the available men at that time. The married sister, being devoted to her husband, followed him to pay homage to the $15^{\text {th }}$ Tirthankara, Dharmanatha, who told them both about their past lives and their proximity to enlightenment. Because the holy man foretold Madanamañjușā that destiny dictated she and her sister ought to liberate together, and the latter still had to be married to a man named Amaraketu, the former, with her husband's blessing, puts her liberation on hold to go find this individual. Amaraketu was a questionable prince, he had been banished from his kingdom because he neglected his princely duties over music and over his scandalous association to a musician's wife. In the good company of his new wife Madanashalākā however, he is able to go back to his kingdom, where she uses her divine powers to calm his enemies and help him get the throne back (Fynes 2005, V.2 229).

Two of the three important characters in this tale were women and they showed piety and acted virtuously all throughout the narrative, yet, although their decision making is textually justified by the influence of destiny, the pathway both sisters took was that which benefited their families and their married life. Both of them put their spiritual path on hold, even though it was at a very advanced stage, to embrace the role of good wives and, with that, empower their husbands. Madanamañjușā only departed in the search of Amaraketu after consulting with her husband. She demonstrates virtuousness 
by respecting the social rules under which a queen ought to act. Madanashalākā used her divine power to frighten her husband's enemies, her clear use of violence is justified by the intention of supporting her king which demonstrates her devotion to him and the rest of her family. Returning to Kelting's work then, I believe that her view on the literary role women have to play is rather positive because, just like Mahmood, she sees these roles as empowering from the perspective of the individuals in question. She argues that many of these roles unarguably embody morality and virtue, yet I believe that even though she is in many aspects correct, the role of women in literature is many times intrinsically negative because, aesthetically they often function as a mere ornament. Their role as intrinsically pious creatures is but a concession that breaks the archetype of the spiritually inferior tempting mistress. I cannot deny that here, women's virtuousness as an example of a patriarchal tool, or an exception to the rule, reflects a rather complex nature. Because the reappearing issue in Indian literature that regards female agency as limited to what is considered correct within their code of conduct, is an issue that revolves around a code recorded and implemented by men. Thus, it is not only ineffective but rather misleading to analyze female agency and virtuousness within that context alone instead of directly comparing it to that of their male counterparts. As far as the Agamas prescribe it, a devout Shravika (or Jain laywomen) portrays virtuousness by the practice of the "right dharma". Their good behavior is characterized by being the encouraging force 
behind their husband, even motivating them to follow the religion of the Jinas when they were from a different religious background (Joshi 2009, 151-2). However, this leaves ample space for the underlying levels of submissive behavior represented through their decision making to untangle: Both sister's blind devotion towards their husband and their acceptance of marriage as a necessary stage in life being but a few examples. Even though this canto mostly revolves around the story of Madanamañjușā, her role is controversial due to the spotlight being laid on Amaraketu. Her pious and virtuous actions as a woman are dimmed by the improper actions of a man. Whether good or bad, women protagonists are limited to a tight spectrum of anticipated choices that restricts both their participation and potential (Kelting 2009, 7).

\section{IV.II Rethinking the Archetypes: The temptress, the Obstinate and the Virtuous.}

As one analyzes LVS's different cantos and starts to untangle the kind of influence their messages could have conveyed, one can finally understand the phrase "better to be than to feign". With this I argue the need, first to understand how female characters are placed within a prescribed set of roles disclosing an underlined negative nature, and second, the need to rethink these characters under a new method that takes the clear existence of human male exceptionalism in these stories as not only a reality but a rather dynamic one indeed. 
As previously discussed in Chapter 2, the correlation between karmic punishment and female births many times becomes apparent. I believe that including the narrative example of female Jina Malli's life here will clarify this statement. This Jina, who is only recognized as a woman by the Svetambara Jains, was the direct reincarnation of monk Mahabala. During his life, Mahabala was dishonest and selfish, he accumulated extra merit by fasting more often than his peers. By lying about the amount of hours he spent meditating and fasting, Mahabala was able to reach enlightenment but, because of his deceitful acts, he was "doomed" to be born a woman. A woman however, who was virtuous in every way, refusing carnal pleasures and violence at a very young age and reaching liberation and Jina-hood as a female (Jaini 2000, 179). This story is a great example of the complexity that women roles take in Jain literature. Female birth is attributed to the fruition of bad karma from previous lives, thus seen as a form of karmic punishment, however, this does not impede their spiritual progress and attainment of Moksha (Appleton 2015, 65). Appleton argues that there is a clearly existing yet undetermined connection between the bad karma attributed to women and their incapability of attaining certain spiritual levels. If one is to analyze the fate of Malli through this scope, her story would become an exception to the rule, an anomalous form of punishment instead of a statement or declaration about women's spiritual potential. Dr. Appleton makes a great observation about the causes "of female birth as only optionally linked to their capabilities 
as women" (Appleton 2015, 62-3). She states that the general understanding of females as intrinsically owning degenerate karmic weight becomes an effective way to justify such limitations (Ibid). This can also be seen through the tale of Rannadi, which is part of the story of Prince Ramadeva and the Consequences of Anger and Violence in the Lìlāvatīsāra. This woman was the reincarnation of Agnisharman, who, being a violent and vengeful man, set a whole town on fire after having murdered his family. Because of the acts of violence committed by this man, his soul was reborn as not only poor and difficult to look at but also as a woman whose inadequate behavior caused her husband to end her life by hitting her in the head with a door bolt (Jinaratnasūri 2005, Vol 1, 119-125).

The problem with women's virtuousness then, starts to become one that portrays women as "the other" and marginalizes the roles they play accordingly. Devout and pious women are seen as exceptions, as rare anomalies that defy the general standards. The virtuous versus capricious female nature is applied to the characters and so the development of their persona becomes limited and reckoned.

Themes regarding the "fickle mindedness and tempting ways" of women as a recurring and generally understood concept in Jain literature across history are certainly represented in the Lìlāvatīsāra (Sethi 2016, 9). To justify this observation, let's compare two very interesting stories: One of a King and 
his Obstinate Queen and one of Surandhara (Jinaratnasūri's 2005, Vol.1 13337, Vol.2 427-47): The first tale, which is a sub-story within the $2^{\text {nd }}$ Canto of the LVS tells us about a king who, having lost his horse in the forest, decided to rest near a creek. There he happened to see a female deity transform into a snake in order to engage in intercourse with another snake. The king deemed the act improper and scared them away with a whip. The goddess went back to her dwelling place and lied to her husband, blaming the king with having suggested obscenities to her. But fate had it that the God, enraged and looking for vengeance, arrived into the king's chambers as he was telling the true events to his wife. As reward for his moral actions, the king is granted a boon that allows him to understand the language of every animal, although telling anyone about it would cause him to lose his life. One day while in the company of his wife, the king listens to the conversation of two lizards. A female lizard asked a male to fetch cosmetics for her, but he refused because her caprice was not worth losing his life for. Laughing out loud, the curiosity of his wife is awakened. She pries and continuously asks him about the cause of his laughter. He, acknowledging her spirit of inquiry, apologizes and tells her that explaining any further would cost him his life. She does not care about such consequences and so, to keep her happy the king begins preparations for his own funeral. As he prepares a pyre, he hears a male goat reply to a female one with: "Am I like that king, that (being able to) unite with another queen, ought to die because of a foolish one? I am not to die over that, without you, there will 
be another". Having heard these words, emphasizing on how foolish it would be to lose one's own life because of the stubborn curiosity of a replaceable woman, the king reconsiders his decision and ignores the wishes of his wife. This story reflects on the intrinsically ill nature of females, not only as humans, but even as animals and deities. Trope rendered as every single female character in the story engendered characteristics such as deceit, carelessness, stubbornness and ignorance.

On the opposite end we have the tale of Surandhara in the $14^{\text {th }}$ Canto of LVS. Surasundari and her sister Priyadarshana are both seen as virtuous and pious women because of their dedication to their husbands and to their duty as wives. Surasundari's father promised her to prince Surandhara without being aware she had already been married to another by the order of her mother. In order to keep his promise, the king gives his second daughter to Surandhara and after some time she feels compelled to tell him the truth about the situation. She insists that her sibling is much more physically and intellectually blessed than she is, which causes the prince to abduct her. This is accomplished with the help of a Vaimanika deity, who was the reincarnation of the prince's friend Dhanavaha. Surasundari refuses Surandhara's lustful wishes again and again, stating that she was happily married to another and her chastity and good behavior were so strong, the god refused to insist on this matter in fear of being set on fire by the power of her virtue. 
What is important to keep in mind with regard to both of these stories is that women in many cases are vilified or venerated as an exceptionality. Jaini makes an important observation when he defines the marginalization of women as "the other" in Jainism. He states that this definition goes far beyond the unanswered biological uncertainties of a religious group, instead, they "lie close to the heart of the sexism that has served as a rationale for the disempowerment of women in all spheres of life, secular and spiritual, in societies of the ancient East and modern West' (Jaini 1991, xxi). In the second story, both these women are considered pious because of how well they fit into the role which was socially prescribed for them, thus they are seen as a special case, as unnaturally pious. Women's innate virtuousness becomes such a rarity it cannot simply be justified by spiritual maturity. The rendering of female corrupt nature on the other hand becomes very clear in the first story. There, were have four female births and three different realms. The goddess is not only deceitful and ill-minded but is also depraved and manipulative. The queen is insensitive, unable to clearly process the consequences of her actions and is seen as an awful woman for showing indifference towards the death of her husband. Both the lizard and the goat were willing to jeopardize the lives of their partners in order to get what they wanted, thus they are seen as oblivious, foolish and unworthy. This story manages to justify the imperfection of a female birth in all three planes of existence, perpetuating a sense of intrinsic inferiority that is to be taken for granted and judged as such. 
The good versus evil nun motif that often reappears through the LVS is another good example of this phenomenon. Nuns (many times ascetics of unspecified religions) tend to be described as fitting into one of the two extremes: some are the epitome of virtuous behavior, being able to grant boons and make use of their omniscience for the benefit of the community while others are described as deceitful hags who had no problem selling their character for a few coins and divulging false teachings. In her book Early India, Thapar (2004) discusses the role of Jain nuns within the Medieval Jain community. Although one could assume otherwise, the number of female renunciates was rather high in these communities. The existence of a secure, socially approved institution along with the possibility of abandoning household responsibilities were but a few factors boosting these numbers up (Thapar 2004, 262). It is because of these reasons however that the reputation of nuns might have caught a negative connotation throughout the period. A link can be drawn between the 'unethical or immoral' nun and those who decide to abandon their earthly possession in order to shed the responsibilities of household duties. Even though it is generally understood by the Jain community that doing so is a clear reflection of spiritual advancement and awakening, we must also have in mind the social consequences that this even would bring into a household and to the husband and sons in question. The possibility of laywomen renouncing created a certain empowerment that in a way jeopardized the role that husbands assumed during that period, thus 
protesting it through the discrediting of wandering nuns becomes a clear possibility.

This ambiguity of female virtuousness becomes rather polemical because it can, oftentimes serve to justify "questionable acts" executed by female characters in the name of religion. As discussed in Chapter 1, when addressing the nature of Pride and Falsehood, Vasundhara, who was a deceitful ascetic who defamed pious Jain monks on many occasions, was tricked by a Jain goddess who introduced herself as a beautiful maiden desirous of a good time. This deity was adamant in teaching Vasundhara a lesson so, while they were in the act of sexual intercourse and he was unaware, she turned into a dog which made things a lot more complicated for the false monk when he got caught in the act. In many other instances, the deeds committed by this goddess would be considered immoral. However, because her conduct was focused on defending the honor of virtuous Jain ascetics, her actions are not disputed. The ambiguity created by their place in the heavenly realm versus their practice of the Jain religion and the decisions they make, puts the goddesses in a problematic position (Sethi 2016, 51-2). It is understood by the Jain community that one can only effectively reach liberation as a human, yet each of these deities still has their own karmic footprint to address and improve. The deeds of the particular goddess are understood as praiseworthy because she became morally questionable for the good of religion. In this example the results of such acts justified her questionable nature. 
In many cases women are not the renouncers but the renounced; they are driven by what benefits their husband or child, not by the sheer desire to develop their spiritual potential. Dr. Sethi attributes this embedded misogyny to an unspoken kind of "gynophobia," a kind of consternation for misunderstood female sexuality and bodily functions that portrays them in literature as "the others". They are represented as objects worthy of praise or hatred yet finding female characters that can be positioned in the middle of these extremes is very rare at best (Sethi 2016, 28). The cultivation of unselfishness, devotion and obedience became the normative idea of female virtuousness (Altekar 1956, 353). There are also many examples in narratives in the Mahabharata for example in which women are deliberately stained and their existence is attributed to the need for men to experience sensual pleasure. In the seventh canto of the Lìlāvatīsāra, in which the consequences of addiction to the pleasures of the sense of touch are discussed, the story of Vimalavahana serves as a great example. This story narrates a quarrel between two kingdoms over ownership of a queen. This queen is described as devout and pious, yet these characteristics are but informative, since the dispute is sparked solely over her looks (Jinaratnasūri's 2005 Vol.1, 469-521).

Altekar puts women's virtuousness in perspective when he states that both Sanskrit and Pali literature refer to the perpetuation of their ethical morality to the absence of an opportunity in which this could be corrupted. These same texts also portray women as completely wicked and amoral, as 
many female characters are considered virtuous because of their adamant disposition towards their male counterparts and not their spiritual competence (Altekar 1956, 320-1). Kelting provides an amazing insight supporting these ideas when she describes the discourse of wifehood in the Jain community as a defining ideology that greatly influences literature and serves as an "instrument of domination used to control which cultural performances are legitimate" (Kelting 2009, 15). The underlying issue with this is the ambiguity behind women's own agency in comparison to that of men.

I believe it is imperative to consider how the relation between words and their range of meanings can greatly affect the way a literary piece is interpreted. Susanne Langer states that just like in nature where certain events are bound to connect "so that the less important might be taken as signs of the more important" (Langer 1956, 58). This phenomenon also applies to the way we interpret language: As the sound of a whistle might serve as the reminder of an approaching train, or a gunshot reminds us of death or danger, the "one-to-one correspondence" between these events creates indisputable links between the object and its meaning to the general audience. Take the example of nuns in medieval Indian narrative as an example: A woman ascetic or nun are often correlated with the idea of spiritual imperfection, thus their presence in text tends to foretell some sort of betrayal or inherent unethical behavior. Enough repetition of these patterns solidifies the negative 
correlation that later branches out into a generalized understanding (Langer 1956, 59).

\section{Conclusion}

After closely examining the many stories of the Lìlāvatīsāra, we cannot deny that the differences between the representation of women in Śvetāmbara Jain canonical and didactic literature are as fascinating as they can be controversial. Interpretation and personification of female virtue is held at the same standard as men's in the former while the latter offers a wide array of possibilities that tend to oscillate in either extreme, classifying women with the label of "other". Female agency in didactive narrative is limited at best; and whether intentionally or not, that is reflected in the secondary roles they play and their inherent ambiguity in comparison to that of their male counterparts. Women's virtuousness and spiritual maturity becomes an exception, it becomes a rare irregularity that disagrees with karmic rules. Themes regarding the "fickle mindedness and tempting ways" of women as a recurring and generally understood concept in Jain literature across history are certainly represented in the LVS and acknowledging this is key to a better understanding of the culture as a whole. I believe that, in order to better understand the cultural and religious evolution of a community, both its canonical and didactive literature must be studied and valued. Closely examining the LVS is but one example of the application of such approach. 


\section{CONCLUSION}

We cannot deny the multiple layers of meaning that didactive narrative is able to transmit. Religiously imbued stories are a colorful example because they often combine the sacred and the mundane thought the illustration of intricate and relatable events. The academic analysis of didactive narrative allows for a deeper understanding of the human mind and its innate desire to find significance in the world. I believe that humans utilize these stories to perpetuate their most fundamental nature. We use our symbolic capacity as a method of universal communication as we express our history, social norms and religious conundrum. This process depends on all other aspects of existence: geography, politics, cultural background of surrounding communities and current state of affairs all influence the way in which we describe our world. Having said this, the human need to perpetuate good behavior through literature becomes slightly clearer. As it was very well stated by scholar Martinez Hewlett, humanity as a whole lies in the awareness of our own history. As meaning-making creatures then, and by the use of narratives, humans factualize topics of importance. Langer states that "facts are our guarantees of truth" $(1956,230)$. And, as she develops on this idea through the final chapters, she argues that the definition of a fact is quite ambiguous and cannot be defined with ease. Nevertheless, these facts are critical in the search and definition of truth and thus are bound to be highlighted in didactive literature. 
Virtue as far as it is represented in Jain medieval narrative, falls under Palmer's definition of intrinsic good. Acting virtuously allows an individual to expedite their own achievement of liberation, meaning that they exercise their agreed upon idea of good behavior in order to reach their on individual goals. Although self-sacrifice as a representation of extrinsic good is analyzed as a separate entity, virtuous behavior shares an innate link with intrinsic good and cannot be so easily defragmented. To help others and facilitate their spiritual growth shows an extrinsic nature that, at the same time, is connected to the individual's ultimate spiritual goal.

The Lìlāvatīsāra illustrates these concepts through clear and straightforward allegory and the development of well-defined archetypes throughout the stories. The assumed simplicity of the script allows for an easier grasp of the prescribed concepts and the generalization of characters allow for an immersive auditory experience. This text does not only transmit sets of vows, it allows the audience to relate and live the adventures of these plain yet impactful characters as they find their way through the cycle of rebirths.

As virtue then is linked with the soul's ultimate spiritual goal, the concepts of karma, fate and human agency are to be considered and analyzed. Karmic residue in this manuscript is directly related to an individual's spiritual clarity, which, at the same time, is what dictates the level of innate 
virtue their persona ought to show. The changes in karmic residue are often justified by the exertion of violence which is based on a rather anthropocentric spiritual hierarchy. Karma serves to justify female births, along with animals and lesser-sensed creatures, as inauspicious and incomplete. By generalizing these standards, women and animals are linked to an inferior nature when compared to human males. Because their whole existence is grouped under these inflexible archetypes, their role as representatives of their whole group becomes very limited and solidifies the idea of a lower spiritual potential. Virtue then, becomes dependent on birth and gender. The normative and generally accepted idea of good behavior that is directly related to one's own spiritual maturity becomes predominantly male while expressions of virtue for female become exclusive representations of obedience and family values. Male virtue is elevated at a spiritual level while the rest of the existing souls are represented in a more mundane light.

What becomes important here is that, although the Lìlāvatīsāra itself is not particularly an authoritative piece, due to the lack of popularity at its time, the stories that the author linked to one another are not exclusively Svetambara or Jain at all. These stories are just but an example of a rich Indic narrative culture that was shared throughout the entirety of India. Thus, the underlying layers of human exceptionalism and socio-religious conflict that the text illustrates allow for a better understanding of the role of narrative at the period in general. 


\section{REFERENCES}

Altekar, Anant Sadashiv. 1956. The Position of Women in Hindu Civilization: From Prehistoric Times to the Present Day. New Delhi: Motilal Banarsidass Publishers.

Appleton, Naomi. 2015. Narrating Karma and Rebirth: Buddhist and Jain Multi-Life Stories. Cambridge University Press.

Bauman, Whitney. Religion and Ecology: Developing a Planetary Ethic. 2014. New York: Columbia Univ. Press.

Berleant, Arnold. 1992.The Aesthetics of Human Environments. Philadelphia: Temple University Press.

Bose, Mandakranta. 2010. Faces of the Feminine in Ancient, Medieval, and Modern India. New York: Oxford University Press.

Bronkhorst, Johannes. 2007. Greater Magadha: Studies in the Culture of Early India. Leiden: Brill.

—. 2011. Karma. Honolulu: University of Hawaii Press.

Bronner, Yigal, David Shulman, and Gary Tubb. 2014. Innovations and Turning Points: Toward a History of Kavya Literature. Oxford: Oxford University Press.

Chapple, Christopher Key, John Thomas Casey, and Haribhadrasūri. 2003. Reconciling Yogas: Haribhadra's Collection of Views on Yoga. Albany: State University of New York Press.

Cort, John E. 2009. "An Epitome of Medieval Śvetambara Jain literary culture a review and study of Jinaratnasuri's Līlāvatīsāra." International Journal of Jaina Studies (Online) 5, no. 1: 1-33. 
- 2001. Jains in the World: Religious Values and Ideology in India. New York: Oxford University Press.

—, ed. 1998. Open Boundaries: Jain Communities and Culture in Indian History. Albany, NY: State University of New York Press.

Day, Terence. 1982. The Conception of Punishment in Early Indian Literature. Wilfrid Laurier University Press.

Emeneau, M.B. 1947. "Studies in the Folk-Tales of India, III: Jain Literature and Kota Folk-Tales." Journal of The American Oriental Society 67, no. 1:1-13.

Flügel, Peter, ed. 2015. Jaina Scriptures and Philosophy. New York: Routledge.

Folkert, Kendall Wayne. 1993. Scripture and Community: Collected Essays on the Jains. Edited by John E. Cort. Atlanta: Scholars Press.

Granoff, Phyllis. 1998. The Forest of Thieves and the Magic Garden: An Anthology of Medieval Jain Stories. New Delhi: Penguin India.

Jacobi, Hermann. 1884. Gaina Suitras. 2 vols. Oxford: The Clarendon Press.

Jaini, Padmanabh S. 2014. The Jaina Path of Purification. Delhi: Motilal Banarsidass Publishers Private Limited.

- 2000. Collected Papers on Jaina Studies. Delhi: Motilal Banarsidass Publ.

- 1991. Gender and Salvation: Jaina Debates on the Spiritual Liberation of Women. Berkeley: University of California.

- 1980. "Karma and the Problem of Rebirth in Jainism." In Karma and Rebirth in Classical Indian Traditions, edited by Wendy Doniger O'Flaherty, 217-38. Berkeley: University of California Press. 
Jinaratnasưri. 2005. The Epitome of Queen Lìlāvatī. Translated by R.C.C. Fynes. New York: New York University Press.

Jinaratnasưri. 1983. Jinaratna's Lìāvatīsarara: A Sanskrit Abridgement of Jineśvara-sừi's Prakrit Līlāvaī-kahā. Edited by Harivallabh Chunilal Bhayani. 96 vols. L.D. Series. Ahmedabad: Lalbhai Dalpatbhai Institute of Indology.

Joshi, Mrinal. 2009. Women in Jainism: A Case Study of Gujarati Inscriptions. Jaipur: Rawat Publications.

Kapadia, Hiralal Rasikdas, and Nagina Ji. Saha. 2010. A History of the Canonical Literature of the Jainas: Revised by the Author. Ahmedabad: Prakrit Text Society.

Kelting, Mary Whitney. 2009. Heroic Wives: Rituals, Stories, and the Virtues of Jain Wifehood. New York: Oxford University Press.

Knight, Christopher C., and Nancey C. Murphy. 2010. Human Identity at the Intersection of Science, Technology and Religion. Farnham: Ashgate.

Langer, Susanne K. 1956. Philosophy in a New Key: A Study in the Symbolism of Reason, Rite and Art. New York: New American Library

Lincoln, Bruce. 2007. Theorizing Myth: Narrative, Ideology, and Scholarship. Chicago: University of Chicago Press.

Mill, John Stuart, and George Nakhnikian. 1972. Nature And: Utility of Religion. Indianapolis: Bobbs-Merrill.

Morgan, Les B., Rāma Karaṇa Sarmā, and Anthony Biduck. 2011. Croaking Frogs a Guide to Sanskrit Metrics and Figures of Speech. Columbia, SC: Mahodara Press.

Palmer, George Herbert. 2010. Nature of Goodness. Nabu Press. 
Pollock, Sheldon I. 2016. A Rasa Reader: Classical Indian Aesthetics. New York: Columbia University Press.

Prasad, Leela. 2007. Poetics of Conduct: Oral Narrative and Moral Being in a South Indian Town. New York: Columbia University Press.

Sethi, Manisha. 2016. Escaping the World: Women Renouncers among Jains. New Delhi: Routledge.

Sethia, Tara, ed. 2004. Ahimsa, Anekānta, and Jaininsm. Delhi: Motilal Banarsidass.

Sukhlalji, Pandit. K. K. Dixit, translator. 2000. Pandit Sukhlalji's Commentary on Tattvārtha Sütra of Vācaka Umāsvāti. L. D. Institute of Indology.

Steiner, George. 1975. After Babel: Aspects of Language and Translation. London.

Tähtinen, Unto. 1976. Ahimsa: Non-Violence in Indian Tradition. London: Rider and Company.

Thapar, Romila. 2004. Early India: From the Origins to AD 1300. Berkeley: University of California Press.

Warder, Anthony Kennedy. 2009. Indian Kavya Literature. 10 vols. Delhi: Motilal Banarsidass. 